\title{
Seabird- induced natural mortality of forage fish varies with fish abundance: Evidence from five ecosystems
}

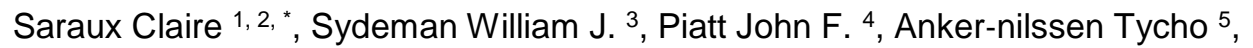 \\ Hentati-sundberg Jonas ${ }^{6}$, Bertrand Sophie ${ }^{7}$, Cury Philippe M. ${ }^{7}$, Furness Robert W. ${ }^{8}$, \\ Mills James A. ${ }^{9}, 10$, Österblom Henrik ${ }^{11}$, Passuni Giannina ${ }^{12}$, Roux Jean-Paul ${ }^{13,14}$, Shannon Lynne J. \\ ${ }^{15}$, Crawford Robert J. M. ${ }^{16}$
}

1 IPHC CNRS Université de Strasbourg Strasbourg, France

2 MARBEC CNRS IRD IFREMER Université de Montpellier Sète ,France

${ }^{3}$ Farallon Institute for Advanced Ecosystem Research Petaluma CA ,USA

4 US Geological Survey Alaska Science Center Anchorage AK ,USA

${ }^{5}$ Norwegian Institute for Nature Research Trondheim, Norway

${ }^{6}$ Department of Aquatic Resources Swedish University of Agricultural Sciences Lysekil ,Sweden

7 IRD UMR MARBEC (Université de Montpellier/CNRS/IRD/IFREMER) Sète, France

8 University of Glasgow Glasgow, UK

${ }^{9}$ Kaikoura, New Zealand

${ }_{10}$ Corning NY, USA

${ }^{11}$ Stockholm Resilience centre Stockholm University Stockholm, Sweden

12 Institute of Hydrobiology and Fisheries Science University of Hamburg Hamburg ,Germany

${ }^{13}$ Namibia Nature Fundation and SEACODE Lüderitz ,Namibia

${ }_{14}$ Ministry of Fisheries and Marine Resources Lüderitz, Namibia

15 Department of Biological Sciences University of Cape Town Cape Town, South Africa

${ }^{16}$ Department of Environment, Forestry and Fisheries Branch Oceans and Coasts Cape Town, South Africa

*Corresponding author : Claire Saraux, email address : claire.saraux@iphc.cnrs.fr

\begin{abstract}
:
Forage fish populations often undergo large and rapid fluctuations in abundance. However, most of their predators are buffered against such fluctuations owing to their slower pace of life, which allows them to maintain more stable populations, at least during short periods of food scarcity. In this study, we investigated top-down processes exerted by seabirds on forage fish stocks in five contrasted marine ecosystems, compiling numerous data sets on seabird counts, diets, energetic needs and prey energy content and abundance. Off Norway, South Africa, Peru, Sweden and Scotland, we found that predation pressure-estimated as the proportion of a fish stock consumed by seabirds - was generally low (median $=1 \%$ ), but increased sharply at low levels of prey abundance. When prey biomass decreased below $15-18 \%$ of its maximum recorded value, predation by seabirds became a source of important additional pressure on prey stocks ( $20 \%$ of prey biomass is consumed by seabirds). An earlier empirical study advocated for keeping forage stocks from falling below a threshold of $33 \%$ of long-term maximum prey biomass in order to safeguard seabird breeding success, but here we further suggest that a threshold of $18 \%$ should be considered as a limit not to be exceeded for the sake of the forage fish themselves, and below which extra cautious management of fisheries may be required. Nevertheless, despite
\end{abstract}


exceptionally high rates of predation on some occasions, predation pressure was not correlated with prey dynamics, suggesting an absence of prey entrapment due to seabirds alone in these five ecosystems.

Keywords : Benguela, Baltic Sea, Humboldt, predator-prey, prey consumption, Shetland 
56 Introduction

\section{Methods}

58 Estimates of seabird consumption and proportion of prey biomass consumed

59 Relationships between consumption and biomass

60 Effect of the predation pressure on-prey dynamics

$61 \quad$ Results

62 Diet

63 Consumption and proportion of prey stock consumed

64 Effect of the predation pressure on prey dynamics

65 Discussion

66 Acknowledgements

67 Data Availability Statement

68 References

69 
Natural mortality $(\mathrm{M})$ is an understudied aspect of fish population biology and fisheries science. In most fisheries' stock assessments, natural mortality is modeled as constant or as a function of size to account both for predation pressure and age (Gislason, Daan, Rice, \& Pope, 2010). However, a growing number of studies suggests that this assumption is incorrect, and that mortality could be density-dependent, or modulated by the environment (Dutil \& Lambert, 2000; Fromentin et al., 2001; Pershing et al., 2015). Because fisheries management often relies on stock assessments which compare fishing mortality (F) to natural mortality, understanding fluctuations in natural mortality is of primary importance. For example, a recent study found up to a $40 \%$ difference between estimates of spawning stock biomass (SSB), F and recruitment (R) in Atlantic cod (Gadus morhua, Gadidae) stock assessments, assuming a constant $M$ versus a variable $M$ linked to body condition (Casini, Eero, Carlshamre, \& Lövgren, 2016). Here, we are interested in examining to what degree natural mortality rates of forage fish may be influenced by seabirds, which are widely distributed and abundant forage fish predators on all continental shelf ecosystems around the world (Cury et al., 2011). Additionally, On top of potential improvement of stock assessment, clarifying predator-prey functional relationships between forage fish and seabirds will also inform ecosystembased management research, e.g. by better understanding how seabird diet relies on forage fish (Dickey-Collas et al., 2014; Peck et al., 2014), and the degree to which mass mortality of seabirds from starvation is exacerbated by low forage abundance and competition with large predatory groundfish for shared prey (Piatt et al., 2020).

Forage fish are consumed by a variety of upper trophic level species in marine ecosystems,

91 including seabirds, marine mammals, and larger piscivorous fish. Typically, and on regional scales, seabirds consume considerably less biomass than marine mammals or especially piscivorous fish 93 (Gaichas et al., 2009) but seabirds can have significant impacts locally (Furness, 1978). In contrast to 94 ectothermic groundfish that need to acquire only about $0.2 \%$ to $1.2 \%$ of their body mass in food daily 95 (Holsman \& Aydin, 2015), endothermic seabirds have high metabolic rates and need to consume 
upwards of $30-80 \%$ of their mass in food daily (Ellis \& Gabrielsen, 2002; Furness, 1990). Combined with the fact that seabirds gather to breed in very large colonies in the thousands to millions (Guinet, Jouventin, \& Malacamp, 1995), this results in a concentration of high energetic demands in a limited area. As central-place foragers, breeding birds return to breeding sites on land (or occasionally ice) to attend and provision offspring, which concentrates foraging areas closer to breeding locations. As a result, some studies have shown localized prey depletion in proximity to island-based colonies, and this may result in intraspecific competition among birds (Ainley et al., 2003; Birt, Birt, Goulet, Cairns, \& Montevecchi, 1987; Lewis, Sherratt, Hamer, \& Wanless, 2001; but see Nur \& Sydeman, 1999). Additionally, most of the forage fish of importance to seabirds are known to exhibit wide fluctuations in abundance in response to climate (e.g. Lluch-Belda et al., 1992) and are often subjected to high fishing mortality (Hilborn et al., 2017; Schwartzlose et al., 1999). Fish abundance often changes much faster than the abundance of predators, because many forage fish predators, including seabirds, have slower life-history characteristics such as high annual survival and delayed sexual maturity, which buffer their breeding populations from fluctuations in food supply (e.g. Hunt, Furness, \& Kerr Building, 1996 and 'canalization hypothesis' Gaillard \& Yoccoz, 2003). Thus the relative predation pressure exerted by seabirds should increase with declines in forage fish stocks, except under extreme conditions where adult seabirds are unable to obtain sufficient food for their own maintenance and survival (Cairns, 1988; Crawford et al., 2011; Erikstad, Fauchald, Tveraa, \& Steen, 1998). Therefore, seabird-induced natural mortality of forage fish could vary strongly with time.

If the proportion of a fish stock consumed by predators increases as biomass decreases, the stock in question may become entrapped, whereby populations cannot overcome predation pressures or easily return to previous levels of abundance (Smout, Rindorf, Hammond, Harwood, \& Matthiopoulos, 2014). Bakun (2006) theoretically explored the functional responses of predators to biomass variation in small pelagic fish, and suggested that predation pressure should be nil when stocks are collapsed at very low levels of biomass (i.e., "refuge abundance"), but increase substantially when fish biomass reaches a level sufficient for predators to be interested in a 
population as prey. At low, but not collapsed biomass, Bakun predicted that 'carnage predation' may

123 hold the population at a relatively low biomass, and coined the term "predator pit" for this

124 mechanism. Predator pits may be maintained until the forage fish population reaches a level

125 sufficient to satiate predators and grow larger at the same time. The addition of human fishing

126 pressure on small pelagic fish populations has been shown to increase the probability of stock

127 collapse but not the duration of the collapse (Essington et al., 2015). Although fishing pressure after

128 a collapse usually drops, or is even halted due to fisheries management and/or profitability, with no

129 change, maintaining fishing effort at lower biomass would likely exacerbate the duration small

130 pelagics are held in a predator pit. To date fisheries impacts and empirically estimated predation

131 pressure have yet to be jointly addressed.

132 In this paper, we test the hypothesis of predator-pit dynamics for forage fish by examining

133 (1) whether the proportion of forage fish stocks consumed by seabirds increases in response to drops

134 in prey biomass, and (2) whether such increases in seabird-induced forage fish mortality affect forage

135 fish population dynamics. To test this hypothesis, we model non-linear relationships between seabird

136 consumption and fish biomass across five ecosystems, and determine the biomass thresholds at

137 which seabirds might begin to exert top-down control on their prey populations. By determining such

138 thresholds in five different ecosystems, this work also tests the generality of top-down control of

139 seabirds on forage fish and identifies local differences, as suggested in (Peck et al., 2014).

141 Methods

142 To estimate seabird predation pressure on forage fish, we use long-term data collected in five

143 contrasted ecosystems on: 1) Atlantic puffin (Fratercula arctica, Alcidae) and Atlantic herring (Clupea

144 harengus, Clupeidae) at Røst off northwest Norway, 2) Cape gannet (Morus capensis, Sulidae) and

145 sardine (Sardinops sagax, Clupeidae) and anchovy (Engraulis encrasicolus, Engraulidae) off western

146 South Africa in the Southern Benguela ecosystem, 3) common murre (Uria aalge, Alcidae) and

147 European sprat (Sprattus sprattus, Clupeidae) in the Baltic Sea, 4) twelve seabird species and lesser 
sandeel (Ammodytes marinus, Ammodytidae) off Shetland and 5) Peruvian booby (Sula variegata,

149 Sulidae), Peruvian pelican (Pelecanus thagus, Pelecanidae) and Guanay cormorant (Phalacrocorax

150 bougainvillii, Phalacrocoracidae) and anchovy (Engraulis ringens, Engraulidae) in the Northern

151 Humboldt ecosystem (Figure 1). While the methodology used (see below) requires a large number of

152 data and constrains the number of ecosystems on which we could test the hypothesis, these five

153 ecosystems enabled investigation of predation pressure in contrasted environments, ranging from

154 productive upwelling regions (Benguela, Humboldt) to the semi-closed Baltic Sea.

155

\section{Estimates of seabird consumption and proportion of prey biomass consumed}

157 To estimate seabird predation pressure, we combined several processes (estimation of bird numbers

158 and population structure, bird energy requirements, bird diet and prey energetic values and

159 abundance) based on a large number of datasets (see similar approaches in Queiros, Fromentin,

160 Astruc, Bauer, \& Saraux, 2018; Van Beveren et al., 2017). In particular, both the quantity consumed

161 by seabirds and the prey stock size were evaluated. A schematic diagram of the general method used

162 in this study is represented in Figure 2.

163 The main challenge of this study was to estimate the total quantity of a given prey that is extracted

164 by seabirds $C_{t}$, meaning that all birds extracting prey should be included, i.e. both adults and chicks,

165 as well as breeders and non-breeders that are present in the area and consume this prey. This was

166 estimated using the formula below:

$$
C_{t}=\frac{P_{t}}{A E * \text { PreyNRJ }} *\left(\begin{array}{c}
D E E_{B} * N_{B, t} * \operatorname{Nbdays}_{B S} \\
+D E E_{N B} * N_{B, t} * \text { Nbdays }_{N B S} \\
+D E E_{N B} * N_{N B, t} * \text { Nbdays }_{\text {col }}
\end{array}\right) * \frac{1}{1000}+C_{\text {chick }, t}
$$

167 Where

168 1) $C_{t}$ is the consumption of the given prey (in tonnes). Note that the $1 / 1000$ in the equation is 169 here only to convert from $\mathrm{kg}$ to tonnes. 
2) $P_{t}$ (unitless) corresponds to the proportion of the given prey in terms of energy in the diet in a given year $t$. Note that in each ecosystem, we assumed $P_{t}$ to be independent of bird age class (chick and adult diet assumed to be the same) and breeding status (see Supplementary material for more details and justifications).

3) $A E$ (unitless) is the assimilation efficiency.

5) $D E E$ (in kJ. $\mathrm{d}^{-1}$ ) is the daily energy expenditure of the birds. As breeding incurs an additional cost, two distinct DEEs were considered: one for breeding birds $D E E_{B}$ and one for nonbreeders or adults in the non-breeding season $D E E_{N B}$.

6) $N_{t}$ (in thousands of birds) represents the number of birds present in the area in year t, either breeding $N_{B, t}$, or non-breeding $N_{N B, t}$.

7) Nbdays (in d) is the number of days during which the prey is consumed by the seabird species in the area. Three periods were distinguished: $\operatorname{Nbdays}_{B S}$ corresponds to the number of days in the breeding season, $\mathrm{Nbdays}_{N B S}$ the duration of the non-breeding season in which breeding birds are present in the colony and finally $\mathrm{Nbdays}_{\mathrm{col}}$ the duration in which non-breeding birds (immature or birds skipping reproduction) are present in the area. Note

8) $C_{\text {chick }}$ (in tonnes) corresponds to the consumption in tonnes made by chicks. This was either calculated through energy requirements and DEE (in the Benguela, Humboldt and Shetland), i.e. $C_{\text {chick }}=\frac{P_{t}}{A E * \text { PreyNRJ }} *\left(D E E_{\text {chick }} * N_{\text {chick }} * N\right.$ bdays $\left._{\text {chickrearing }}\right)$ or directly from meal size given to the chicks (in Norwegian and Baltic Seas): $C_{\text {chick }}=P_{\text {mass }, t} * N_{\text {chick }} *$ Nbdays $_{\text {chickrearing }} *$ Mealsize 
192 Once the consumption of a prey is estimated, it needs to be compared to the prey stock biomass to

193 estimate the predation pressure. Fish biomass was estimated either through stock assessment 194 models, or from direct acoustic biomass estimates, depending on the ecosystem (see Table 1 Only in 195 the North Sea (case study Shetland Islands), did natural mortality (M) explicitly include bird 196 consumption. Yet, while predator consumption included that of seabirds and marine mammals, the most important predators of sandeels by far are fish - especially mackerel, herring, cod, haddock, whiting, and gurnard, so that there should be little effect of seabird consumption on M (ICES-HAWG, 2020; ICES-WKSand, 2016). Further, stock biomass should represent the entire fish biomass present before seabird consumption occurred. Depending on the timing of stock biomass assessment and seabird consumption phenology, stock biomass had to be corrected. In the Humboldt, the production model estimates the biomass available each month, so that no correction was needed. Similarly, no corrections were applied in the Baltic, where stock assessment refers to the start of spawning (i.e.

204 April), just before seabirds start consuming sprats and in the Norwegian Sea, where stock 205 assessments refer to the first of January, i.e. before the predation events. By contrast, acoustic 206 biomass estimates in the Benguela derive from November acoustic surveys and a stock assessment 207 model in the Shetland estimates biomass on the $1^{\text {st }}$ of July. In both cases, most of seabird consumption occurred beforehand, so that stock biomass was corrected by adding seabird consumption. Finally, the fish biomasses presented here represented annual estimates of the stock, and not fish availability within foraging range of the birds around the colonies, so that we are

211 estimating the predation pressure on the stock and not local prey depletion. However, it has to be 212 noted that in some large ecosystems, regional scales were used (e.g. we considered the southern 213 sub-system of the Benguela, located off South-Africa and not the entire Benguela ecosystem). Spatial 214 scales can be found in Table 1 for each ecosystem.

215 Although the approach was the same everywhere, differences appeared in the estimation of these 216 parameters because of species and ecosystem specificity. For instance, gannets in the Southern 217 Benguela are resident seabirds and consumption outside of the breeding period had to be 
218 considered in order to estimate the entire predation pressure they exerted on sardine and anchovy

219 stocks, while migrating Atlantic puffins are present in the eastern Norwegian Sea only for a few 220 months in order to breed.

221 As some seabird data were not always available in each ecosystem, some assumptions had to be 222 made (see summary in Table 1). While these were done to best fit our knowledge of the ecosystem 223 or the species at play, they introduce uncertainty in our estimates of consumption and predation 224 pressure. Nevertheless, we applied the same methodology through time within each ecosystem and 225 among ecosystems. This allowed us to investigate temporal trends and compare among ecosystems, 226 and to identify the magnitude of top-down effects. The main assumptions and parameters are 227 summarized for each ecosystem in Table 1 and details about the specificities as well as monitoring 228 methods are detailed in supplementary material. Note that in the case of the Atlantic puffin in the 229 Norwegian Sea, two different scenarios of consumption were run in the absence of diet data outside 230 the chick-rearing period. The first assumed that puffins consumed herring during the entire time they 231 are present at the colony while the minimum consumption scenario assumed herring consumption 232 only during chick-rearing (see Supplementary material).

233 Predation pressure was then estimated as the percentage of the stock consumed by seabirds,

234 calculated as: $\operatorname{Pred}_{t}=100 * \frac{C_{t}}{B_{t}}$.

\section{Relationships between consumption and biomass}

236 In order to examine functional responses of seabird diet and aggregated prey consumption $C_{t}$ to prey

237 biomass, for each relationship we tested a selection of six a priori parametric models (null model 238 assuming no link of seabird diet or consumption with prey biomass $y=a$; linear model assuming a 239 constant increase of seabird diet or consumption with fish biomass $y=a * B+b$; second-order 240 polynomial model assuming an optimum fish biomass for seabirds $y=a * B+b * B+c$; as well as 241 exponential, logarithmic and power models which all assume non-linearities and some sort of 242 thresholds above or below which seabirds react differently to prey $y=a * e^{-b * B}, y=a * \ln (B)+$ $\left.243 b, y=a * B^{b}\right)$. When looking at the relationship between seabird aggregated consumption and 
244 stock biomass, we also tested two additional models: type II and III functional responses: $C_{t}=\frac{a * B}{1+b * B}$ 245 and $\left.C_{t}=\frac{a * B}{1+b * B^{2}}\right)$. Because data in the Shetland were only collected in 3 years, they are only 246 presented as a qualitative indication and no model was performed for this ecosystem. Also, in the 247 Humboldt, no model was performed for the diet data in the absence of annual estimated diet (diet 248 was estimated by period in this ecosystem). All models were fitted using non-linear least square 249 adjustment and the best fit was selected based on the lowest AICc values to avoid over250 parameterization (Piatt et al., 2007). When change in AICc ( $\triangle \mathrm{AICC}$ ) was less than 2 between the two 251 best models, the more parsimonious model was chosen. All models within a $\triangle \mathrm{AICc}$ of 2 are presented 252 along with the null model in Table 2. Once the numerical relationships between stock biomass and 253 the percentage of the stock consumed by seabirds were established, we used a change-point analysis 254 to identify thresholds within non-linear relationships (Andersen, Carstensen, Hernández-García, \& Duarte, 2009; Cury et al., 2011). The threshold in biomass was then expressed relatively to the maximum biomass observed in the time-series (i.e. $\%$ threshold $=100 * \frac{\text { threshold }}{\text { Max } B}$ ).

\section{Effect of the predation pressure on-prey dynamics}

259 To investigate whether the predation pressure exerted by seabirds might impact prey dynamics, we examined the correlations between prey biomass and the number of avian predators or the percentage of the stock that was consumed the previous year. Because stock biomass time series are often autocorrelated, residuals were checked for autocorrelation. While autocorrelation was never 263 significant in the Baltic Sea, residuals from the models in the Humboldt and Benguela all displayed 264 positive autocorrelation of order 1 (detected through the pacf function in R). To account for that, a 265 one-year lagged time series of the stock biomass was added as an explanatory variable in the 6 models $\left(B_{t} \sim N_{t-1}+B_{t-1}\right.$ and $B_{t} \sim \operatorname{Pred}_{t-1}+B_{t-1}$ for sardine and anchovy in the Benguela and for anchovy in the Humboldt). Finally, we also studied the relationship between the change in prey biomass (i.e. $\left.\Delta B=\mathrm{B}_{\mathrm{t}}-\mathrm{B}_{\mathrm{t}-1}\right)$ and the percentage of the stock consumed at $\mathrm{t}-1\left(\Delta B \sim \operatorname{Pred}_{t-1}\right)$. These 
relationships were not investigated in Shetland due to too few data points and in the Norwegian Sea,

270 where puffins consume age 0 herring that first recruit to the spawning stock at age 3 . The 271 relationship between this herring's spawning stock biomass and its recruitment three years later is 272 weak (Sætre, Toresen, \& Anker-Nilssen, 2002).

\section{Results}

\section{Diet}

276 The percentage contributions of various prey species to the seabird predators included in our study

277 are shown in Figure 3. For Atlantic puffins from 1982-2006, the contribution by mass of age 0 herring 278 to the diet (46 $\pm 22 \%$ [13-89\%]) was not significantly related to the biomass of age 0 herring (Figure 2794 a, Table 2). For common murres, the mean contribution by mass of sprat to the diet from 20022802012 was very high and stable across time (98 $\pm 2 \%$; range $93-100 \%$ ), regardless of the biomass of 281 sprat (Figure 4d). In the Humboldt ecosystem, the contribution of anchovy in the diet was usually 282 quite high $(81 \pm 8 \%$ ) but dropped significantly in El-Niño years (55\% for cormorants and $58 \%$ for 283 boobies and pelicans; Figure 3b). For Cape gannets, the mean contribution by mass of sardine to the 284 diet from 1978-2011 was $30 \pm 19 \%$ (range $2-61 \%$ ) and that of anchovy $28 \pm 16 \%$ (range 3-62\%; 285 Figure $3 e$ ). The average combined contribution of these two prey species to the diet was $58 \pm 14 \%$ 286 (range 16-77\%; Figure 3e). In both cases, the percentage of fish in gannet diet increased with fish 287 stock biomass, although the relationships differed (Table 2; Figure 4e \& 4f). Finally, at Shetland the 288 average contribution by mass of sandeel to the diet of 12 seabirds decreased from $88 \pm 4 \%$ in 1977 289 and $83 \pm 5 \%$ in 1986 to only $45 \pm 10 \%$ in 2000 (Figure 3c).

\section{Consumption and proportion of prey stock consumed}

292 The consumption of age 0 herring by Atlantic puffins at Røst (regardless of the scenario used) and the 293 consumption of anchovy by boobies, cormorants and pelicans in the Humboldt ecosystem were not 294 significantly related to the prey stock biomass (Figure 5a \& 5b, Table 2). However, consumption of 
sardine and anchovy by Cape gannets in the southern Benguela ecosystem was significantly

296 positively related to the biomasses of these prey species by a type II functional response (Figure 5e \& 5f). Similarly, the consumption of sandeels by 12 seabird species at Shetland seemed to increase with the biomass of sandeels (Figure 5c). Finally, the consumption of sprats by common murres in the Baltic Sea decreased with sprat biomass following a power model (Figure $5 \mathrm{~d}$ ). The predation pressure, as estimated by the percentage of the fish biomass consumed by seabirds, was generally low (median $=1 \%$ across all years and ecosystems; Figure 6 ). While this was true in most cases ( $\leq 20 \%$ in $95 \%$ of the cases), the predation pressure increased when fish abundance was low (Figure 6).

304 Further, in four ecosystems (it was not tested for Shetland due to few data points), all relationships were best fitted by power models. While the proportion of the stock consumed remained extremely 306 low in the Baltic Sea (0.5-1.2\%; Figure 6d), it increased sharply in other ecosystems once fish biomass 307 decreased below a certain threshold. This threshold was lower than the median biomass observed in 308 the series (Figure 6) and varied between 15 and 18\% of the maximum observed prey biomass (15\% 309 for herring in the Norwegian Sea regardless of the scenario Figure 6a, 16\% for both anchovy and sardine in the Benguela Figure $6 \mathrm{e} \& 6 \mathrm{f}$ and $18 \%$ for anchovy in the Humboldt Figure $6 \mathrm{~b})$.

Effect of the predation pressure on prey dynamics

313 Autocorrelation in the residuals was positive and of order 1 in all models explaining prey stock

314 biomass, except for the Baltic, where no autocorrelation was detected. Stock biomass at $\mathrm{t}-1$ was thus 315 added as an explanatory variable in the models (except for the Baltic) and had a significant positive 316 effect on prey biomass at $\mathrm{t}$ in all relevant models (all $\mathrm{P}<0.009$ ). In the Humboldt, while prey biomass 317 was positively related to the number of seabirds present at $\mathrm{t}-1$, and negatively to the percentage of 318 the stock consumed by seabirds at $t-1$, both relationships disappeared after accounting for 319 autocorrelation (Fig. 7 a \& d). In the Benguela, the sardine stock biomass was positively related to 320 the number of birds present the previous year (regardless of the autocorrelation, Fig 7c), but not to 
321 the percentage of the stock consumed the year before (Fig. 7f). The anchovy stock biomass in the

322 Benguela was not related to either the number of gannets or the proportion of prey consumed by

323 gannets in the previous year (Fig 7c \& f). Sprat biomass was negatively related to both the number of

324 murres the previous year and the proportion of stock that they consumed (Fig 7b \& e).

325 Finally, the change in fish biomass from one year to another was not related to the percentage of the 326 stock consumed the previous year in any of the ecosystems (Figure 7g \& 7h \&7i).

\section{Discussion}

329 Many studies advocate that seabirds are good bioindicators of marine ecosystems (e.g. Cairns, 1988;

330 Piatt et al., 2007), although an implied assumption and frequent observation is that these

331 ecosystems are regulated by bottom-up processes (Aebischer, Coulson, \& Colebrook, 1990;

332 Frederiksen, Edwards, Richardson, Halliday, \& Wanless, 2006; Speckman, Piatt, Minte-Vera, \&

333 Parrish, 2005). However, aquatic ecosystems are complex and may also be regulated by numerous

334 biological interactions, including predation and competition. For instance, whole-lake experiments

335 showed that trophic cascades could inhibit the response of primary producers to nutrient inputs

336 (Carpenter et al., 2001). The existence of such top-down mechanisms or trophic cascades, which had

337 previously been reported only from terrestrial ecosystems or lakes, has now been demonstrated in

338 marine ecosystems (Ainley, Ballard, \& Dugger, 2006), especially after overfishing (Baum \& Worm,

339 2009; Casini et al., 2009; Frank, Petrie, Choi, \& Leggett, 2005; Österblom, Casini, Olsson, \& Bignert,

340 2006). Further studies have proposed that marine ecosystems might be regulated by alternating

341 bottom-up and top-down processes (Cury et al., 2008; Litzow \& Ciannelli, 2007), or a "wasp-waist"

342 interaction of the two (Fauchald, Skov, Skern-Mauritzen, Johns, \& Tveraa, 2011), and that relative

343 strength of bottom-up and top-down control may vary spatially (Frederiksen, Furness, \& Wanless,

344 2007). For example, marine heatwaves can markedly increase metabolic rates and food demands of

345 ectothermic groundfish and trigger temporary top-down control of prey populations and increased

346 competition with seabirds for shared prey (Barbeaux, Holsman, \& Zador, 2020; Piatt et al., 2020). 
348 pressure exerted by seabirds on forage fish in five different ecosystems. Because this requires a large

349 quantity of data on both seabirds and forage fish, it was necessary to sometimes make assumptions

350 that could have a marked effect on model outcomes. In the Norwegian Sea for instance, due to the

351 absence of diet data outside of the chick-rearing period, we had to consider two extreme scenarios:

352 i.e., either puffins do not eat herring outside the chick-rearing season, or they consume herring

353 during the entire breeding season. The latter scenario (i.e. maximum consumption) yielded some

354 unrealistically high values (>100\% of prey stock). However, such outcomes could also result from the

355 uncertainty associated with calculating prey biomass in this ecosystem. Indeed, puffins eat age-0

356 herring, the biomass of which is not directly assessed (see the ESM for more details). Still, we believe

357 the relationships we found likely reflect qualitatively the true relationship (in terms of shape) as we

358 applied our methods consistently between years and between ecosystems but actual estimates

359 under that scenario were less reliable.

360 With respect to seabird diets, we found that different species displayed marked differences

361 in response to fluctuations in prey abundance. Seabird species have different locomotion and

362 foraging strategies which limit the distance that they can forage from colonies, or the depth to which

363 they can feed (e.g. Shealer, 2002). Large seabirds are, for instance, often less vulnerable to prey

364 depletion due to greater travelling capacities and greater energetic efficiencies (Ellis \& Gabrielsen,

365 2002; Furness \& Tasker, 2000), which might explain the absence of seabird response to prey biomass

366 decrease in the Humboldt system in typical (i.e. non El-Niño) conditions. The non-linear relationships

367 between abundance of sardine and anchovy and the contribution of these species to the diet of Cape

368 gannets off western South Africa suggest that gannets are able to maintain their intake of these

369 species over a wide range of biomass variability. Cape gannets have indeed been shown to be flexible

370 in their foraging effort and duration to track sardines and anchovies, their preferred prey even when

371 abundance decreases or spatial distribution shifts (Green et al., 2015). However, below a certain

372 threshold of prey biomass, gannets were not able to compensate anymore and had to shift their diet 
towards other prey. Recent research off the south coast of South Africa has shown that in the post-

374 guard stage (>50 days) of chick-rearing, foraging range is extended and gannet diet may differ from

375 that in the guard stage as a consequence of changes either in prey abundance and distribution, or in

376 the energetic requirements of growing offspring (Botha \& Pistorius, 2018). A similar relationship was

377 evident for the average proportion of sandeel in the diets of seabirds at the Shetland Islands. Yet,

378 this masks important differences between species, with Arctic skua (Stercorarius parasiticus,

379 Stercorariidae) and Arctic tern (Sterna paradisaea, Laridae) maintaining $100 \%$ of their sandeel diet in

380 all three periods of study, whereas the sandeel contribution to diet decreased from $70-80 \%$ to less

381 than $10 \%$ in gannet (Morus bassanus, Sulidae), fulmar (Fulmarus glacialis, Procellariidae), great skua

382 (S. skua, Stercorariidae) and great black-backed gull (Larus marinus, Laridae) between 1977 and

383 2000. Small surface-feeders, such as Arctic terns, are more constrained and, as such, more vulnerable

384 to environmental changes than other species (Baird, 1990; Furness \& Tasker, 2000; Shealer, 2002).

385 Seabird diet, body size and the ability to switch to other prey when their favored prey is depleted

386 might then be important components of their sensitivity to environmental or fisheries-induced

387 fluctuations in prey.

These results highlight the importance of forage fish accessibility for seabirds rather than just abundance. Indeed, a decrease in forage fish stock biomass does not automatically translate into a decrease in forage fish availability or catchability for seabirds, or at least not linearly, due to possible changes in spatial distribution. First, the shoaling behaviour of most forage fish means that

392 predation, like fisheries catches, may be maintained even when prey abundance decreases (in

393 fisheries known as hyperstability of catches, Hilborn \& Walters, 1992). For example, as stock biomass

394 decreases, forage fish may concentrate in their most suitable habitat (i.e., the basin hypothesis;

395 MacCall, 1990), resulting in habitat contractions, but no decrease in fish density. In this study, the

396 absence of relationships between seabird diet and forage fish abundance in the Humboldt system

397 was in line with previous works which showed that except in the case of extreme El Niño events,

398 seabird behavior, breeding seasonality and population dynamics were affected by fish accessibility 
rather than fish abundance (Barbraud et al., 2017; Boyd et al., 2015, 2016, 2017; Passuni et al., 2018,

400 2015). Anchovy spatial distribution was shown to be strongly correlated with oxygen levels 401 (Bertrand, Ballón, \& Chaigneau, 2010), so that when the oxycline goes up, anchovies are 402 concentrated close to the surface, where they become accessible to shallow divers such as Peruvian boobies and Peruvian pelicans (Weimerskirch, Bertrand, Silva, Bost, \& Peraltilla, 2012). This phenomenon may be apparent also in the Benguela with respect to anchovy accessibility to both purse-seine fishers as well as surface-diving predators, since unpublished evidence suggests that anchovy in recent periods are located closer to the sea bed given reduced stratification (and more homogenous oxygen levels) through the water column (SWG-PEL of Department of Environments, Forestry and Fisheries in South Africa 2019).

Our results show that the predation pressure from seabirds, i.e. the proportion of the stock consumed by seabirds, was generally low (median $=1 \%$ and $\leq 20 \%$ of stock size in $95 \%$ of cases),

411 confirming that bottom-up processes might be controlling seabird - forage fish interactions most of 412 the time at the population scale. It is important to note that our analyses occurred at a regional or 413 ecosystem scale, so that our results did not consider the potential for local prey depletion (Lewis et 414 al., 2001) or the importance of top-down processes on spatial distribution at a fine scale. The broad 415 scale used in this study might also explain why the estimated predation pressure was lower than that obtained by some previous studies (Furness, 1978). Nonetheless, when prey biomass decreased 417 below a certain threshold (here estimated between 15 and $18 \%$ of the maximum biomass depending 418 on the ecosystem and always lower than the median biomass), the predation pressure increased 419 sharply as depicted by power relationships between prey biomass and the percentage of prey 420 biomass consumed by seabirds. While it could not be tested in Shetland due to the small number of 421 years monitored, this held true in the Norwegian Sea, in the Humboldt and in the Benguela. In 422 contrast, the percentage of the sprat stock consumed by common murres in the Baltic Sea remained 423 extremely low $(\leq 1.2 \%)$ throughout the study. This could be explained by the high abundance and 424 small variability in sprat biomass during the study period (Eero, 2012), which in fourteen years did 
not fall below $54 \%$ of its maximum value (a value well above the $15 \%$ threshold detected in other

426 ecosystems). An increase in the proportion of prey that is consumed by predators when prey

427 abundance is low was not unexpected, because predators need to satisfy their food requirements

428 (Bakun, 2006) and even though some are able to switch their diet to alternative food sources, they

429 may preferentially target energetically-rewarding prey (Adams \& Klages, 2010). Due to different life-

430 histories between short-lived prey and long-lived predators, and the canalization of seabird adult

431 survival, i.e. the key parameter buffering their population dynamics against temporal fluctuations

432 (Gaillard \& Yoccoz, 2003), the number of seabirds can still be high after a decrease in prey biomass,

433 maintaining prey consumption at high levels. In some exceptional cases, the predation pressure we

434 estimated became extremely high, such as in the Norwegian Sea, where this most likely reflected

435 unrealistic survival rates for herring in the modelling for some of the poorest years (cf. ICES, 2012

436 and Supplementary material for further details).

437 A rapid rise in the proportion of forage fish consumed, i.e. in predation mortality, once 438 forage fish have been depleted below a certain threshold of abundance, might result in their 439 entrapment in a predator pit (Bakun, 2006). This effect would be exacerbated if proportions of those 440 prey taken by other predators in the ecosystem (e.g. other seabirds, seals, cetaceans, predatory fish, 441 see Table S1) increase similarly and fishing mortality is also high. For several fish stocks in the North442 West Atlantic, including Atlantic herring, chub mackerel (Scomber colias, Scombridae), haddock 443 (Melanogrammus aeglefinus, Gadidae) and silver hake (Merluccius bilinearis, Merlucciidae) empirical 444 evidence suggested that recruitment remained poor when stocks were reduced to $10 \%$ of pristine 445 levels, but that good year-classes were experienced, and stock rebuilding took place when biomass 446 was above about $20 \%$ of peak levels of abundance (Brown, Anthony, Anderson, Hennemuth, \& 447 Sherman, 1983). Here, we found that predation pressure increased sharply when the stock biomass 448 decreased below 15 to $18 \%$ of its maximum abundance. These observations raise the question as to 449 whether such predation pressure might constrain prey stocks and keep them at very low levels. 
451 were highlighted in both the Benguela and Humboldt ecosystems. While this might appear 452 surprising, it could be due to temporal autocorrelation in prey biomass time series, i.e. the fact that a 453 high prey biomass in a given year is likely to be followed by another high prey biomass the next year 454 and vice versa (Fréon, Cury, Shannon, \& Roy, 2005). If the ecosystem is indeed under bottom-up control, or both prey and predators react the same way to other external variables, then both would endure similar favourable or unfavourable periods, explaining the positive relationship between prey at $\mathrm{t}+1$ and predator at $\mathrm{t}$. Indeed, a partial temporal autocorrelation of lag 1 was present in the residuals of the models in the Benguela and the Humboldt. Once we removed the autocorrelation by adding a one-year lagged time series of the prey biomass as a covariate in the model, both 460 relationships between prey biomass and predator abundance or consumption disappeared in the 461 Humboldt. Further, a negative temporal correlation of predator and prey abundance, despite being 462 the most commonly used approach to investigate predation (e.g. Frank et al., 2005; Worm \& Myers, 463 2003), does not allow one to distinguish between predators driving prey dynamics and both 464 populations responding in opposite directions to an external environmental driver (Hunt \& 465 McKinnell, 2006; Oken \& Essington, 2015). When looking at the effect of the predation pressure, 466 instead of the number of predators, on the prey biomass a year later, no relationship was detected in 467 the Humboldt or Benguela ecosystems. In contrast, a significant negative relationship between prey 468 biomass and the number of birds or the percentage of the stock consumed by seabirds the year 469 before was found in the Baltic Sea. Given the very low predation pressure $(<1.2 \%)$ estimated in this 470 ecosystem, we suggest that this might be due to a spurious correlation, perhaps attributable to a 471 third variable to which sprat and murres might react differently. Finally, looking at how predation 472 pressure affects the change in prey biomass from one year to another, rather than the absolute value 473 of biomass, should remove the variance explained by temporal autocorrelation and enable an 474 investigation of the immediate effects of predation, whereas the effect on absolute biomass might 475 be delayed (Oken \& Essington, 2015). Importantly, no relationships were highlighted between these 
two variables, suggesting that seabird predation pressure did not drive changes in forage fish 477 abundance.

However, it should be borne in mind that we only estimated a portion, often small (e.g. Shannon, Christensen, \& Walters, 2004), of the overall natural mortality, as consumption by other predators present in the area (large predatory fish, marine mammals, other seabirds) was not included. Further, predators do not target the entire population, but rather focus on given length- (or age-) classes, making the effect of predation harder to detect (Oken \& Essington, 2015). Hence, in years when prey biomass is low and corresponding seabird consumption requires a significant part of the forage fish stock, strong competition might arise between predators and fisheries. During such intense competition, as created in the North Pacific by the massive biennial fluctuations in predatory adult pink salmon (Ruggerone, Springer, Shaul, \& van Vliet, 2019; Springer \& Van Vliet, 2014) or during the 2014-2016 marine heatwave when all forage fish stocks crashed simultaneously (Jones et al., 2018; Piatt et al., 2020; von Biela et al., 2019), it is increasingly apparent that seabirds may take the brunt of competitive displacement from food supplies (e.g. 10-20\% of the NE Pacific population of common murres died en masse from starvation during the heatwave; Piatt et al., 2020).In the California current, seabirds whose diet is mainly forage fish, especially anchovy, respond negatively to forage fisheries (Koehn et al., 2017). While economic consequences of fishing forage fish are unclear for piscivorous fisheries (Engelhard et al., 2014), the impact on conservation of seabirds and marine mammals might tip the scales towards keeping forage fish at sea being more valuable than fishing them out (Koehn et al., 2017). Many seabirds have an unfavourable conservation status. Seabirds are more threatened, and declining faster, than other groups of birds (Dias et al., 2019). For example, nine of 15 seabird species $(60 \%)$ that breed in the Benguela ecosystem are classified, in terms of criteria of the International Union for the Conservation of Nature (IUCN), as Endangered, Vulnerable or Near-threatened; these include three that feed mainly on sardine and anchovy, whereas several seabirds that do not compete with fisheries for food have a Red List status of Least Concern (Crawford, 2013; IUCN, 2019). Cury et al. (2011) identified a threshold of approximately 
one-third of maximum prey biomass below which seabird breeding success was consistently reduced

503 and more variable. Similarly, when the biomass of sardine spawners fell below c. $25 \%$ of its maximum

504 observed value, survival of adult African penguins (Spheniscus demersus, Spheniscidae) decreased

505 markedly (Robinson, Butterworth, \& Plagányi, 2015) and survival and numbers breeding decreased

506 for three Benguela seabirds when a forage availability index reached low values (Crawford, Sydeman,

507 Thompson, Sherley, \& Makhado, 2019). There may be a still lower ecological threshold (15 to $18 \%$

508 according to our study) where prey species, or at least spatial components of prey stocks (e.g. west

509 coast vs. south coast in the Benguela), suffer high rates of natural and fishing mortality. Interestingly,

$51020 \%$ of maximum biomass is often used in fishery management as a limit biomass $\left(B_{\text {lim }}\right)$ below which

511 a stock should not fall or a recovery plan should be put in place. Here, we confirm a similar threshold

512 and advise fishery managers to exercise due care in allocating allowable catches or fishing licenses,

513 etc. at low levels of abundance.

514 To conclude, our study is important as it contributes to the growing literature in support of

515 an ecosystem approach to fisheries (EAF; Dickey-Collas et al., 2014; Hill et al., 2020; Koehn et al.,

516 2017; Pikitch et al., 2004). While top-down processes due to predation of forage fish by seabirds did

517 not seem to control forage fish dynamics in any of the five ecosystems we considered, the predation

518 pressure sometimes attained high levels, which signals the need for fisheries management to

519 account for ecosystem constraints when setting catch limits in periods of low forage fish biomass.

520 Finally, our results (and in particular the differences of sensitivity of seabird diet to prey biomass

521 among species) also suggest that forage fish accessibility might be more important than forage fish

522 abundance depending on the ecophysiological constraints that apply to seabirds (e.g. depth to which

523 they can dive). As a consequence, fish stock management should not only ensure a safe level of fish

524 biomass for the stock to be sustainable and the predators to feed (Cury et al., 2011), but also focus

525 on safeguarding predator foraging grounds. Measures such as spatial enclosure around breeding

526 sites have for instance been used in different areas (see (Sydeman et al., 2017) for more on the 
subject). Spatial planning is thus an extremely important component of human activity (and

528 especially fishery) management in order to safeguard all components of the ecosystem.

\section{Acknowledgements}

531 This work was partly funded by the Baltic Sea Ecosystem Adaptive Management program, Benguela Current Commission, Department of Environment, Forestry and Fisheries (DEFFA, South Africa), by the cooperative agreement between the Institut de Recherche pour le Développement (IRD, France),

534 the Peruvian Sea Institute (IMARPE), and the International Joint Laboratory DISCOH, by a grant from

535 MISTRA to the Stockholm Resilience Centre, the National Research Foundation (NRF, South Africa,

536 through its incentive programme), the Norwegian Environment Agency and the SEAPOP programme

537 (Norwegian Research Council, grant 192141), the South African Research Chair Initiative funded

538 through the South African Department of Science and Technology and administered by the NRF, and

539 the USGS Alaska Science Center. We thank J. C. Coetzee (Department of Agriculture, Forestry and

540 Fisheries, South Africa) for making available time series of biomass estimates of sardine and anchovy

541 off South Africa, ICES for use of similar data on Atlantic herring and a large number of people (none

542 mentioned, none forgotten) who assisted with data collection. The paper is an output of the "One-

543 third for the Birds Working Group", which held meetings at Sète, France in 2010, Boulders, South

544 Africa in 2011, Kasitsna Bay, Alaska, USA in 2012 and Stora Karlsö, Sweden in 2013. Finally, we wish

545 to thank Dr Laura Koehn and an anonymous reviewer for their constructive comments on the 546 manuscript. Any use of trade, firm, or product names is for descriptive purposes only and does not

547 imply endorsement by the U.S. Government.

\section{Data Availability Statement}

549 The data that support the findings of this study are openly available in Mendeley data at 550 http://dx.doi.org/10.17632/5bb8nhb6hr.1 


\section{References}

553

554

555

556

557

558

559

560

561

562

563

564

565

566

567

568

569

570

571

572

573

Adams, N. J., Abrams, R. W., Siegfried, W. R., Nagy, K. A., \& Kaplan, I. R. (1991). Energy expenditure and food consumption by breeding Cape gannets Morus capensis. Marine Ecology Progress Series. Inter-Research Science Center. https://doi.org/10.2307/24816793

Adams, N. J., \& Klages, N. T. W. (2010). Foraging effort and prey choice in Cape gannets. South African Journal of Marine Science, 21(1), 157-163. https://doi.org/10.2989/025776199784126060

Aebischer, N. J., Coulson, J. C., \& Colebrook, J. M. (1990). Parallel long-term trends across four marine trophic levels and weather. Nature, 347(6295), 753-755. https://doi.org/10.1038/347753a0

Ainley, D. G., Ballard, G., Barton, K. J., Karl, B. J., Rau, G. H., Ribic, C. a, \& Wilson, P. R. (2003). Spatial and temporal variation of diet within a presumed metapopulation of Adelie penguins. Condor, 105(1), 95-106.

Ainley, D. G., Ballard, G., \& Dugger, K. M. (2006). Competition among penguins and cetaceans reveals trophic cascades in the Western Ross Sea, Antarctica. Ecology, 87(8), 2080-2093. https://doi.org/10.1890/0012-9658(2006)87[2080:CAPACR]2.0.CO;2

Andersen, T., Carstensen, J., Hernández-García, E., \& Duarte, C. M. (2009). Ecological thresholds and regime shifts: approaches to identification. Trends in Ecology \& Evolution, 24(1), 49-57. https://doi.org/10.1016/J.TREE.2008.07.014

Anker-Nilssen, T., \& Aarvak, T. (2006). Long-term studies of seabirds in the municipality of Røst, Nordland. Results with focus on 2004 and 2005. Trondheim.

Anker-Nilssen, T., \& Øyan, H. S. (1995). Long-term studies of the breeding biology of puffins at Røst. 
Augustyn, J., Cockroft, A., Kerwath, S., Lamberth, S., Githaigi-Mwicigi, J., Pitcher, G., ... Auerswald, I. (2018). South Africa. In B. F. Phillips \& M. Perez-Ramirez (Eds.), Climate change impacts in fisheries and aquaculture: a global analysis (pp. 479-522). John Wiley and Sons Inc.

Baird, P. H. (1990). Influence of Abiotic Factors and Prey Distribution on Diet and Reproductive Success of Three Seabird Species in Alaska. Ornis Scandinavica, 21(3), 224. https://doi.org/10.2307/3676782

Bakun, A. (2006). Wasp-waist populations and marine ecosystem dynamics: Navigating the "predator pit" topographies. Progress in Oceanography, 68(2-4), 271-288. https://doi.org/10.1016/J.POCEAN.2006.02.004

Barbeaux, S. J., Holsman, K., \& Zador, S. (2020). Marine Heatwave Stress Test of Ecosystem-Based Fisheries Management in the Gulf of Alaska Pacific Cod Fishery. Frontiers in Marine Science, 7, 703. https://doi.org/10.3389/fmars.2020.00703

Barbraud, C., Bertrand, A., Bouchón, M., Chaigneau, A., Delord, K., Demarcq, H., ... Bertrand, S. (2017). Density dependence, prey accessibility and prey depletion by fisheries drive Peruvian seabird population dynamics. Ecography. https://doi.org/10.1111/ecog.02485

Barrett, R. T., Gabrielsen, G. W., \& Fauchald, P. (1995). Prolonged incubation in the Atlantic puffin (Fratercula arctica) and evidence of mild hypothermia as an enegry-saving mechanisms. In H. R. Skojdal, C. Hopkins, K. E. Erikstad, \& H. P. Leinaas (Eds.), Ecology of fjords and coastal waters (pp. 479-488). Amsterdam: Elsevier Science.

Batchelor, A. L., \& Ross, G. J. B. (1984). The diet and implications of dietary change of Cape Gannets on Bird Island, Algoa Bay. Ostrich, 55(2), 45-63. https://doi.org/10.1080/00306525.1984.9634757

Baum, J. K., \& Worm, B. (2009). Cascading top-down effects of changing oceanic predator 

2656.2009.01531.x

Berruti, A., Underhill, L. G., Shelton, P. A., Moloney, C., \& Crawford, R. J. M. (1993). Seasonal and Interannual Variation in the Diet of Two Colonies of the Cape Gannet (Morus capensis) between 1977-78 and 1989. Colonial Waterbirds, 16(2), 158. https://doi.org/10.2307/1521434

Bertrand, A., Ballón, M., \& Chaigneau, A. (2010). Acoustic Observation of Living Organisms Reveals the Upper Limit of the Oxygen Minimum Zone. PLoS ONE, 5(4), e10330. https://doi.org/10.1371/journal.pone.0010330

Birt, V., Birt, T., Goulet, D., Cairns, D. K., \& Montevecchi, W. A. (1987). Ashmole's halo: direct evidence for prey depletion by a seabird. Marine Ecology Progress Series. Retrieved from http://www.int-res.com/articles/meps/40/m040p205.pdf

Botha, J. A., \& Pistorius, P. A. (2018). Variability in the Foraging Distribution and Diet of Cape Gannets between the Guard and Post-guard Phases of the Breeding Cycle. Frontiers in Marine Science, 5, 15. https://doi.org/10.3389/fmars.2018.00015

Boyd, C., Castillo, R., Hunt, G., Punt, A., VanBlaricom, G., Weimerskirch, H., \& Bertrand, S. (2015). Predictive modelling of habitat selection by marine predators with respect to the abundance and depth distribution of pelagic prey. Journal of Animal Ecology, 84, 1575-1588. Retrieved from https://besjournals.onlinelibrary.wiley.com/doi/abs/10.1111/13652656.12409\%4010.1111/\%28ISSN\%291365-2656.MovementEcology

Boyd, C., Grünbaum, D., Hunt, G. L., Punt, A. E., Weimerskirch, H., \& Bertrand, S. (2016). Effectiveness of social information used by seabirds searching for unpredictable and ephemeral prey. Behavioral Ecology, 27(4), 1223-1234. Retrieved from https://academic.oup.com/beheco/article-abstract/27/4/1223/1744926 
Boyd, C., Grünbaum, D., Hunt, G. L., Punt, A. E., Weimerskirch, H., \& Bertrand, S. (2017). Effects of variation in the abundance and distribution of prey on the foraging success of central place foragers. Journal of Applied Ecology, 54(5), 1362-1372. https://doi.org/10.1111/13652664.12832

Brekke, B., \& Gabrielsen, G. (1994). Assimilation efficiency of adult Kittiwakes and Brunnich's Guillemots fed Capelin and Arctic Cod. Polar Biology, 14(4), 279-284. https://doi.org/10.1007/BF00239177

Brown, B. E., Anthony, V. C., Anderson, E. D., Hennemuth, R., \& Sherman, K. (1983). The dynamics of pelagic fishery resources off the northeastern coast of the United States under conditions of extreme fishing perturbations (North Western Atlantic).

Cairns, D. K. (1988). Seabirds as indicators of marine food supplies. Biological Oceanography, 5, 261271.

Carpenter, S. R., Cole, J. J., Hodgson, J. R., Kitchell, J. F., Pace, M. L., Bade, D., ... Schindler, D. E. (2001). Trophic cascades, nutrients, and lake productivity: whole-lake experiments. Ecological Monographs, 71(2), 163-186. https://doi.org/10.1890/00129615(2001)071[0163:TCNALP]2.0.CO;2

Casini, M., Eero, M., Carlshamre, S., \& Lövgren, J. (2016). Using alternative biological information in stock assessment: Condition-corrected natural mortality of Eastern Baltic cod. ICES Journal of Marine Science. https://doi.org/10.1093/icesjms/fsw117

Casini, M., Hjelm, J., Molinero, J. C., Lövgren, J., Cardinale, M., Bartolino, V., ... Kornilovs, G. (2009). Trophic cascades promote threshold-like shifts in pelagic marine ecosystems. Proceedings of the National Academy of Sciences of the United States of America, 106(1), 197-202. https://doi.org/10.1073/pnas.0806649105 
643 Coetzee, J., Merkle, D., de Moor, C., Twatwa, N., Barange, M., \& Butterworth, D. (2008). Refined 644 estimates of South African pelagic fish biomass from hydro-acoustic surveys: quantifying the 645 effects of target strength, signal attenuation and receiver saturation. African Journal of Marine Science, 30(2), 205-217. https://doi.org/10.2989/AJMS.2008.30.2.1.551

Cooper, J. (1978). Energetic Requirements for Growth and Maintenance of the Cape Gannet (Aves; Sulidae). Zoologica Africana, 13(2), 305-317. https://doi.org/10.1080/00445096.1978.11447631

Crawford, R. J. M. (2013). Long-term change in the population sizes and conservation status of South Africa's seabirds. Ostrich, 84(2), v-ix. https://doi.org/10.2989/00306525.2013.819661

Crawford, R. J. M., Altwegg, R., Barham, B., Barham, P., Durant, J., Dyer, B., ... Whittington, P. (2011). Collapse of South Africa's penguins in the early 21st century. African Journal of Marine Science, 33(1), 139-156. https://doi.org/10.2989/1814232X.2011.572377

Crawford, R. J. M., Dundee, B. L., Dyer, B. M., Klages, N. T. W., Meÿer, M. A., \& Upfold, L. (2007). Trends in numbers of Cape gannets (Morus capensis), 1956/1957-2005/2006, with a consideration of the influence of food and other factors. ICES Journal of Marine Science, 64(1), 169-177. https://doi.org/10.1093/icesjms/fsl011

Crawford, R. J. M., Ryan, P. G., \& Williams, A. J. (1991). Seabird consumption and production in the Benguela and Western Agulhas ecosystems. South African Journal of Marine Science, 11(1), 357-375. https://doi.org/10.2989/025776191784287709

Crawford, R. J. M., Sydeman, W. J., Thompson, S. A., Sherley, R. B., \& Makhado, A. B. (2019). Food habits of an endangered seabird indicate recent poor forage fish availability off western South Africa. ICES Journal of Marine Science, 76(5), 1344-1352. https://doi.org/10.1093/icesjms/fsz081 
666 Cury, P. M., Boyd, I. L., Bonhommeau, S., Anker-Nilssen, T., Crawford, R. J. M., Furness, R. W., ... Sydeman, W. J. (2011). Global Seabird Response to Forage Fish Depletion--One-Third for the

Cury, P. M., Shin, Y., Planque, B., Durant, J., Fromentin, J., Kramerschadt, S., ... Grimm, V. (2008). Ecosystem oceanography for global change in fisheries. Trends in Ecology \& Evolution, 23(6),

Dias, M. P., Martin, R., Pearmain, E. J., Burfield, I. J., Small, C., Phillips, R. A., ... Croxall, J. P. (2019). Threats to seabirds: A global assessment. Biological Conservation. Elsevier Ltd. https://doi.org/10.1016/j.biocon.2019.06.033

Dickey-Collas, M., Engelhard, G. H., Rindorf, A., Raab, K., Smout, S., Aarts, G., ... Peck, M. A. (2014). Ecosystem-based management objectives for the North Sea: riding the forage fish rollercoaster. ICES Journal of Marine Science, 71(1), 128-142. https://doi.org/10.1093/icesjms/fst075

Dunn, E. H. (1975). Caloric Intake of Nestling Double-Crested Cormorants. The Auk, 92(3), 553-565. https://doi.org/10.2307/4084609

Dutil, J.-D., \& Lambert, Y. (2000). Natural mortality from poor condition in Atlantic cod (Gadus morhua). Canadian Journal of Fisheries and Aquatic Sciences, 57(4), 826-836.

Eero, M. (2012). Reconstructing the population dynamics of sprat (Sprattus sprattus balticus) in the Baltic Sea in the 20th century. ICES Journal of Marine Science, 69(6), 1010-1018. (Eds.), Biology of marine birds (pp. 359-407). 

portal.org/smash/record.jsf?pid=diva2\%3A279689\&dswid=page

691 Engelhard, G. H., Peck, M. A., Rindorf, A., C. Smout, S., Van Deurs, M., Raab, K., ... Dickey-Collas, M. (2014). Forage fish, their fisheries, and their predators: Who drives whom? ICES Journal of

Erikstad, K. E., Fauchald, P., Tveraa, T., \& Steen, H. (1998). On the Cost of Reproduction in Long-Lived Birds: The Influence of Environmental Variability. Ecology, 79(5), 1781.

696 https://doi.org/10.2307/176796

Essington, T. E., Moriarty, P. E., Froehlich, H. E., Hodgson, E. E., Koehn, L. E., Oken, K. L., ... Stawitz, C. Academy of Sciences of the United States of America, 112(21), 6648-6652. https://doi.org/10.1073/pnas.1422020112

Fauchald, P., Skov, H., Skern-Mauritzen, M., Johns, D., \& Tveraa, T. (2011). Wasp-Waist Interactions in the North Sea Ecosystem. PLoS ONE, 6(7), e22729.

Frank, K. T., Petrie, B., Choi, J. S., \& Leggett, W. C. (2005). Trophic cascades in a formerly coddominated ecosystem. Science, 308(5728), 1621-1623. to top predators: bottom-up control of a marine food web across four trophic levels. Journal of Animal Ecology, 75(6), 1259-1268. https://doi.org/10.1111/j.1365-2656.2006.01148.x top-down processes in controlling sandeel abundance in the North Sea. Marine Ecology 
713

714

715

716

717

718

719

720

721

722

723

724

725

726

727

728

729

730

731

732

733

734

Fréon, P., Cury, P., Shannon, L., \& Roy, C. (2005). Sustainable Exploitation of Small Pelagic Fish Stocks Challenged by Environmental and Ecosystem Changes: A Review. Bulletin of Marine Science, 76(2), 385-462. Retrieved from https://www.ingentaconnect.com/content/umrsmas/bullmar/2005/00000076/00000002/art00 013

Fromentin, J. M., Myers, R. A., Bjørnstad, O. N., Stenseth, N. C., Gjøsæter, J., \& Christie, H. (2001). Effects of density-dependent and stochastic processes on the regulation of cod populations. Ecology, 82(2), 567-579. https://doi.org/10.1890/0012-9658(2001)082[0567:EODDAS]2.0.CO;2

Furness, R. (1978). Energy Requirements of Seabird Communities: A Bioenergetics Model. The Journal of Animal Ecology, 47(1), 39. https://doi.org/10.2307/3921

Furness, R. (1990). A preliminary assessment of the quantities of Shetland sandeels taken by seabirds, seals, predatory fish and the industrial fishery in 1981-83. Ibis, 132(2), 205-217. https://doi.org/10.1111/j.1474-919X.1990.tb01039.x

Furness, R., \& Tasker, M. (2000). Seabird-fishery interactions: quantifying the sensitivity of seabirds to reductions in sandeel abundance, and identification of key areas for sensitive seabirds in the North Sea. Marine Ecology Progress Series, 202, 253-264. https://doi.org/10.3354/meps202253

Gaichas, S., Skaret, G., Falk-Petersen, J., Link, J. S., Overholtz, W., Megrey, B. A., ... Aydin, K. (2009). A comparison of community and trophic structure in five marine ecosystems based on energy budgets and system metrics. Progress in Oceanography, 81(1-4), 47-62. https://doi.org/10.1016/j.pocean.2009.04.005

Gaillard, J. M., \& Yoccoz, N. G. (2003). Temporal variation in survival of mammals: a case of environmental canalization? Ecology, 84(12), 3294-3306. https://doi.org/10.1890/02-0409 
Gislason, H., Daan, N., Rice, J. C., \& Pope, J. G. (2010). Size, growth, temperature and the natural mortality of marine fish. Fish and Fisheries. https://doi.org/10.1111/j.1467-2979.2009.00350.x

Goya, E. (2000). Abunduncia de aves guaneras y su relacion con la pesqueria de anchoveta peruana de 1953 a 1999.

Green, D. B., Klages, N. T. W., Crawford, R. J. M., Coetzee, J. C., Dyer, B. M., Rishworth, G. M., \& Pistorius, P. A. (2015). Dietary change in Cape gannets reflects distributional and demographic shifts in two South African commercial fish stocks. ICES Journal of Marine Science, 72(3), 771781. https://doi.org/10.1093/icesjms/fsu203

Guinet, C., Jouventin, P., \& Malacamp, J. (1995). Satellite remote sensing in monitoring change of seabirds: use of Spot Image in king penguin population increase at lle aux Cochons, Crozet Archipelago. Polar Biology, 15(7), 511-515. https://doi.org/10.1007/BF00237465

Hedgren, S. (1975). The breeding population of Guillemot Uria aalge in the Baltic Sea. Vår Fågelvärld, $34,43-52$.

Hilborn, R., Amoroso, R. O., Bogazzi, E., Jensen, O. P., Parma, A. M., Szuwalski, C., \& Walters, C. J. (2017). When does fishing forage species affect their predators? Fisheries Research, 191, 211221. https://doi.org/10.1016/J.FISHRES.2017.01.008

Hilborn, R., \& Walters, C. J. (1992). Quantitative fisheries stock assessment: Choice, dynamics and uncertainty. Reviews in Fish Biology and Fisheries, 2(2), 177-178. https://doi.org/10.1007/BF00042883

Hill, S. L., Hinke, J., Bertrand, S., Fritz, L., Furness, R. W., lanelli, J. N., ... Ratcliffe, N. (2020). Reference points for predators will progress ecosystem-based management of fisheries. Fish and Fisheries, faf.12434. https://doi.org/10.1111/faf.12434

Hilton, G. M., Furness, R. W., \& Houston, D. C. (2000). A comparative study of digestion in North 

048X.2000.310106.x

760

Holsman, K. K., \& Aydin, K. (2015). Comparative methods for evaluating climate change impacts on the foraging ecology of Alaskan groundfish. Marine Ecology Progress Series, 521, 217-235. https://doi.org/10.3354/MEPS11102

Hunt, G. L., Furness, R. W., \& Kerr Building, G. (1996). ICES Cooperative research report. https://doi.org/10.17895/ices.pub.4624

Hunt, G. L., \& McKinnell, S. (2006). Interplay between top-down, bottom-up, and wasp-waist control in marine ecosystems. Progress in Oceanography, 68(2-4), 115-124. https://doi.org/10.1016/j.pocean.2006.02.008

ICES-HAWG. (2020). Herring Assessment Working Group Report.

ICES-WKSand. (2016). Report of the benchmark workshop on sandeel. Begren, Norway.

ICES. (2012). Report of the Working Group on Widely Distributed Stocks (WGWIDE). Lowestoft.

ICES. (2018). ICES Advice on fishing opportunities, catch, and effort. Sprat (Sprattus sprattus) in subdivisions 22-32 (Baltic Sea).

IUCN. (2019). Red List of Threatened Species. Retrieved November 7, 2019, from www.iucnredlist.org

Jahncke, J., Checkley, D. M., \& Hunt, G. L. (2004). Trends in carbon flux to seabirds in the Peruvian upwelling system: effects of wind and fisheries on population regulation. Fisheries Oceanography, 13(3), 208-223. https://doi.org/10.1111/j.1365-2419.2004.00283.x

Jarvis, M. J. F. (1974). The Ecological Significance of Clutch Size in the South African Gannet (Sula capensis (Lichtenstein). The Journal of Animal Ecology, 43(1), 1. https://doi.org/10.2307/3154

Jones, T., Parrish, J. K., Peterson, W. T., Bjorkstedt, E. P., Bond, N. A., Ballance, L. T., ... Harvey, J. 

(2018). Massive Mortality of a Planktivorous Seabird in Response to a Marine Heatwave. Geophysical Research Letters, 45(7), 3193-3202. https://doi.org/10.1002/2017GL076164@10.1002/(ISSN)2169-9291.MMH1

783

784

785

786

787

788

Kadin, M., Olsson, O., Hentati-Sundberg, J., Ehrning, E. W., \& Blenckner, T. (2016). Common Guillemot Uria aalge parents adjust provisioning rates to compensate for low food quality. Ibis, 158(1), 167-178. https://doi.org/10.1111/ibi.12335

Kadin, M., Österblom, H., Hentati-Sundberg, J., \& Olsson, O. (2012). Contrasting effects of food quality and quantity on a marine top predator. Marine Ecology Progress Series, 444, 239-249. https://doi.org/10.3354/meps09417

Koehn, L. E., Essington, T. E., Marshall, K. N., Sydeman, W. J., Szoboszlai, A. I., \& Thayer, J. A. (2017). Trade-offs between forage fish fisheries and their predators in the California Current. ICES Journal of Marine Science, 74(9), 2448-2458. https://doi.org/10.1093/icesjms/fsx072

Laugksch, R. C., \& Duffy, D. C. (1984). Energetics equations and food consumption of seabirds in two marine upwelling areas: comparisons and the need for standardization. South African Journal of Marine Science, 2(1), 145-148. https://doi.org/10.2989/02577618409504365

Lewis, S., Sherratt, T. N., Hamer, K. C., \& Wanless, S. (2001). Evidence of intra-specific competition for food in a pelagic seabird. Nature, 412(6849), 816-819. https://doi.org/10.1038/35090566

Litzow, M. A., \& Ciannelli, L. (2007). Oscillating trophic control induces community reorganization in a marine ecosystem. Ecology Letters, 10(12), 1124-1134. https://doi.org/10.1111/j.14610248.2007.01111.x

Lluch-Belda, D., Schwartzlose, R. A., Serra, R., Parrish, R., Kawasaki, T., Hedgecock, D., \& Crawford, R. J. M. (1992). Sardine and anchovy regime fluctuations of abundance in four regions of the world oceans: a workshop report. Fisheries Oceanography, 1(4), 339-347. 
804 MacCall, A. D. (1990). Dynamic geography of marine fish populations. Seattle: University of Washington.

806

807

808

809

810

811

812

813

814

815

816

817

818

820

Martin, A. R. (1989). The diet of Atlantic Puffin Fratercula arctica and Northern Gannet Sula bassana chicks at a Shetland colony during a period of changing prey availability. Bird Study, 36(3), 170180. https://doi.org/10.1080/00063658909477022

Mitchell, P. I., Newton, S. F., Ratcliffe, N., \& Dunn, T. E. (2004). Seabird Populations of Britain and Ireland: results of the seabird 2000 census (1998-2002). London. Retrieved from http://www.jncc.defra.gov.uk/page-1530.

Nur, N., \& Sydeman, W. J. (1999). Survival, breeding probability and reproductive success in relation to population dynamics of brandt's cormorants phalacrocorax penicillatus. Bird Study, 46, S92S103. https://doi.org/10.1080/00063659909477236

Oken, K. L., \& Essington, T. E. (2015). How detectable is predation in stage-structured populations? Insights from a simulation-testing analysis. Journal of Animal Ecology, 84(1), 60-70. https://doi.org/10.1111/1365-2656.12274

Oliveros-Ramos, R., \& Peña, C. (2011). Modeling and analysis of the recruitment of peruvian anchovy (Engraulis ringens) between 1961 and 2009. Ciencias Marinas, 37(4B), 659-674. Retrieved from http://www.redalyc.org/articulo.oa?id=48021256010

Olsson, O., \& Hentati-Sundberg, J. (2017). Population trends and status of four seabird species (Uria aalge, Alca torda, Larus fuscus, Larus argentatus) at Stora Karlsö in the Baltic Sea. Ornis Svecica, 27(2-4), 64-93. https://doi.org/10.34080/os.v27.19558

Österblom, H., Casini, M., Olsson, O., \& Bignert, A. (2006). Fish, seabirds and trophic cascades in the Baltic Sea. Marine Ecology Progress Series, 323, 233-238. https://doi.org/10.3354/meps323233 
Øyan, H. S., \& Anker-Nilssen, T. (1996). Allocation of Growth in Food-Stressed Atlantic Puffin Chicks. The Auk, 113(4), 830-841. https://doi.org/10.2307/4088861

Passuni, G., Barbraud, C., Chaigneau, A., Bertrand, A., Oliveros-Ramos, R., Ledesma, J., ... Bertrand, S. (2018). Long-term changes in the breeding seasonality of Peruvian seabirds and regime shifts in the Northern Humboldt Current System. Marine Ecology Progress Series, 597, 231-242. https://doi.org/10.3354/meps12590

Passuni, G., Barbraud, C., Chaigneau, A., Demarcq, H., Ledesma, J., Bertrand, A., ... Bertrand, S. (2015). Seasonality in marine ecosystems: Peruvian seabirds, anchovy and oceanographic conditions. Ecology, 97(1), 150708023447006. https://doi.org/10.1890/14-1134.1

Peck, M. A., Neuenfeldt, S., Essington, T. E., Trenkel, V. M., Takasuka, A., Gislason, H., ... Rice, J. C. (2014). Forage Fish Interactions: a symposium on "Creating the tools for ecosystem-based management of marine resources." ICES Journal of Marine Science, 71(1), 1-4. https://doi.org/10.1093/icesjms/fst174

Pedersen, J., \& Hislop, J. R. G. (2001). Seasonal variations in the energy density of fishes in the North Sea. Journal of Fish Biology, 59(2), 380-389. https://doi.org/10.1111/j.10958649.2001.tb00137.x

Pershing, A. J., Alexander, M. A., Hernandez, C. M., Kerr, L. A., Le Bris, A., Mills, K. E., ... Thomas, A. C. (2015). Slow adaptation in the face of rapid warming leads to collapse of the Gulf of Maine cod fishery. Science, 350(6262), 809-812. https://doi.org/10.1126/science.aac9819

Piatt, J. F., Harding, A., Shultz, M., Speckman, S., van Pelt, T., Drew, G., \& Kettle, A. (2007). Seabirds as indicators of marine food supplies: Cairns revisited. Marine Ecology Progress Series, 352, 221234. https://doi.org/10.3354/meps07078

Piatt, J. F., Parrish, J. K., Renner, H. M., Schoen, S. K., Jones, T. T., Arimitsu, M. L., ... Sydeman, W. J. 

(2020). Extreme mortality and reproductive failure of common murres resulting from the northeast Pacific marine heatwave of 2014-2016. PLOS ONE, 15(1), e0226087.

Pikitch, E. K., Santora, C., Babcock, E. A., Bakun, A., Bonfil, R., Conover, D. O., ... Sainsbury, K. J. (2004). Ecosystem-Based Fishery Management. Science, 305(5682), 346. https://doi.org/10.1126/science.1098222

Queiros, Q., Fromentin, J., Astruc, G., Bauer, R. R. K., \& Saraux, C. (2018). Dolphin predation pressure on pelagic and demersal fish in the Northwestern Mediterranean Sea. Marine Ecology Progress Series, 603, 13-27. https://doi.org/10.3354/meps12672

Robinson, W. M. L., Butterworth, D. S., \& Plagányi, É. E. (2015). Quantifying the projected impact of the South African sardine fishery on the Robben Island penguin colony. ICES Journal of Marine

Roth, J. E., Nur, N., Warzybok, P., \& Sydeman, W. J. (2008). Annual prey consumption of a dominant 862 Science: Journal Du Conseil, 72(6), 1822-1833. https://doi.org/10.1093/icesjms/fsv035

864

865

866

867 seabird, the common murre, in the California Current system. ICES Journal of Marine Science, 65(6), 1046-1056. https://doi.org/10.1093/icesjms/fsn077

Ruggerone, G., Springer, A., Shaul, L., \& van Vliet, G. (2019). Unprecedented biennial pattern of birth and mortality in an endangered apex predator, the southern resident killer whale, in the eastern North Pacific Ocean. Marine Ecology Progress Series, 608, 291-296. https://doi.org/10.3354/meps12835

Sætre, R., Toresen, R., \& Anker-Nilssen, T. (2002). Factors affecting the recruitment variability of the Norwegian spring-spawning herring (Clupea harengus L.). ICES Journal of Marine Science, 59(4), 725-736. https://doi.org/10.1006/jmsc.2002.1180 
Schwartzlose, R. A., Alheit, J., Bakun, A., Baumgartner, T. R., Cloete, R., Crawford, R. J. M., ... Zuzunaga, J. Z. (1999). Worldwide large-scale fluctuations of sardine and anchovy populations. South African Journal of Marine Science, 21(1), 289-347. https://doi.org/10.2989/025776199784125962

Shannon, L. J., Christensen, V., \& Walters, C. J. (2004). Modelling stock dynamics in the southern Benguela ecosystem for the period 1978-2002. African Journal of Marine Science, 26(1), 179196. https://doi.org/10.2989/18142320409504056

Shealer, D. A. (2002). Foraging behaviour and food of seabirds. In E. A. Schreiber \& J. Burger (Eds.), Biology of marine birds (pp. 137-177). CRC Press.

Smout, S., Rindorf, A., Hammond, P. S., Harwood, J., \& Matthiopoulos, J. (2014). Modelling prey consumption and switching by UK grey seals. ICES Journal of Marine Science, 71(1), 81-89. https://doi.org/10.1093/icesjms/fst109

Speckman, S. G., Piatt, J. F., Minte-Vera, C. V., \& Parrish, J. K. (2005). Parallel structure among environmental gradients and three trophic levels in a subarctic estuary. Progress in Oceanography, 66(1), 25-65. https://doi.org/10.1016/j.pocean.2005.04.001

Springer, A. M., \& Van Vliet, G. B. (2014). Climate change, pink salmon, and the nexus between bottom-up and top-down forcing in the subarctic Pacific Ocean and Bering Sea. Proceedings of the National Academy of Sciences of the United States of America, 111(18). https://doi.org/10.1073/pnas.1319089111

Sydeman, W. J., Thompson, S. A., Anker-Nilssen, T., Arimitsu, M., Bennison, A., Bertrand, S., ... Zador, S. (2017). Best practices for assessing forage fish fisheries-seabird resource competition. 
896

Toresen, R., \& $\varnothing$ stvedt, O. J. (2000). Variation in abundance of Norwegian spring-spawning herring (Clupea harengus, Clupeidae) throughout the 20th century and the influence of climatic fluctuations. Fish and Fisheries, 1(3), 231-256. https://doi.org/10.1111/j.14672979.2000.00022.x

Van Beveren, E., Fromentin, J.-M., Bonhommeau, S., Nieblas, A.-E., Metral, L., Brisset, B., ... Saraux, C. (2017). Predator-prey interactions in the face of management regulations: changes in Mediterranean small pelagic species are not due to increased tuna predation. Canadian Journal of Fisheries and Aquatic Sciences, 74(9), 1422-1430. https://doi.org/10.1139/cjfas-2016-0152

von Biela, V., Arimitsu, M., Piatt, J. F., Heflin, B., Schoen SK Trowbridge, J., \& Clawson, C. (2019). Extreme reduction in nutritional value of a key forage fish during the Pacific marine heatwave of 2014-2016. Marine Ecology Progress Series, 613, 171-182. https://doi.org/10.3354/meps12891

Walsh, P., Halley, D., Harris, M., del Nevo, A., Sim, L., \& Tasker, M. (1995). Seabird monitoring handbook. Retrieved from http://nora.nerc.ac.uk/id/eprint/8798/1/Bird1.pdf

Weimerskirch, H., Bertrand, S., Silva, J., Bost, C., \& Peraltilla, S. (2012). Foraging in Guanay cormorant and Peruvian booby, the major guano-producing seabirds in the Humboldt Current System. Marine Ecology Progress Series, 458, 231-245. https://doi.org/10.3354/meps09752

Worm, B., \& Myers, R. A. (2003). Meta-analysis of cod-shrimp interactions reveals top-down control in oceanic food webs. Ecology, 84(1), 162-173. https://doi.org/10.1890/00129658(2003)084[0162:MAOCSI]2.0.CO;2 


\begin{tabular}{|c|c|c|c|c|c|c|c|c|}
\hline & $\begin{array}{c}\text { Proportion of } \\
\text { prey in diet in } \\
\text { terms of } \\
\text { energy } \\
P_{t}\end{array}$ & $\begin{array}{c}\text { Assimilation } \\
\text { Efficiency } \\
A E\end{array}$ & $\begin{array}{c}\text { Prey energetic } \\
\text { value } \\
\text { PreyNRJ }\end{array}$ & $\begin{array}{c}\text { Daily Energy } \\
\text { Expenditure } \\
D E E\end{array}$ & $\begin{array}{c}\text { Bird numbers } \\
\qquad N_{t}\end{array}$ & $\begin{array}{c}\text { Number of } \\
\text { days } \\
\text { Nbdays }\end{array}$ & $\begin{array}{c}\text { Chick } \\
\text { consumption } \\
C_{\text {chick }}\end{array}$ & Fish biomass \\
\hline $\begin{array}{l}\text { Atlantic puffin } \\
\text { in the } \\
\text { Norwegian Sea }\end{array}$ & $\begin{array}{c}\text { Chick=Adult } \\
\text { diet } \\
\text { Annual values } \\
\text { (Anker-Nilssen } \\
\text { \& Aarvak, } \\
\text { 2006; updated } \\
\text { with } \\
\text { www.seapop.n } \\
\underline{\text { o/en) }}\end{array}$ & $\begin{array}{c}0.7 \text { (Brekke \& } \\
\text { Gabrielsen, } \\
\text { 1994) }\end{array}$ & $\begin{array}{c}3.7 \text { kJ.g } \\
1 \text { (Anker- } \\
\text { Nilssen \& } \\
\varnothing \text { yan, 1995) }\end{array}$ & 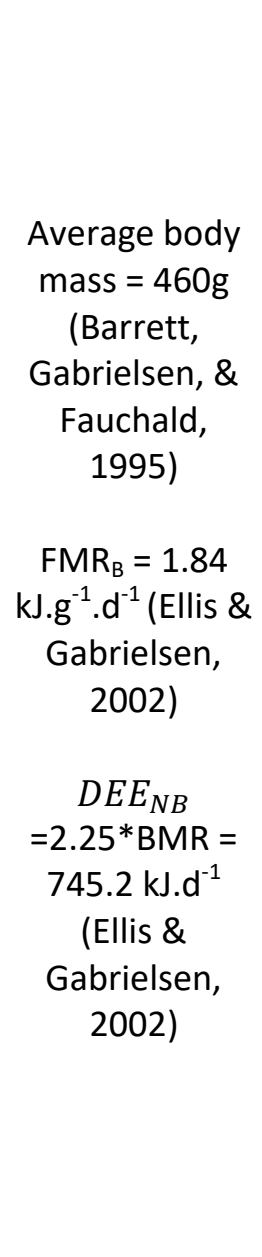 & $\begin{array}{c}\text { Røst } \\
\text { population } \\
\mathrm{N}_{\mathrm{B}, \mathrm{t}} \text { estimated } \\
\text { from counts } \\
\text { (Anker-Nilssen } \\
\text { \& Aarvak, } \\
\text { 2006; updated } \\
\text { with } \\
\text { www.seapop.n } \\
\text { o/en) } \\
\text { N } \\
\text { imb,t }=\text { nb of } \\
\text { immature from } \\
\text { 1 to } 5 \\
\text { (estimated } \\
\text { from number } \\
\text { of fledglings } \\
\text { and juvenile } \\
\text { survival; } \\
\text { Sandvik, } \\
\text { Erikstad, } \\
\text { Fauchald, \& } \\
\text { Tveraa, 2008) + } \\
25 \% \text { of mature } \\
\text { birds skipping } \\
\text { reproduction }\end{array}$ & 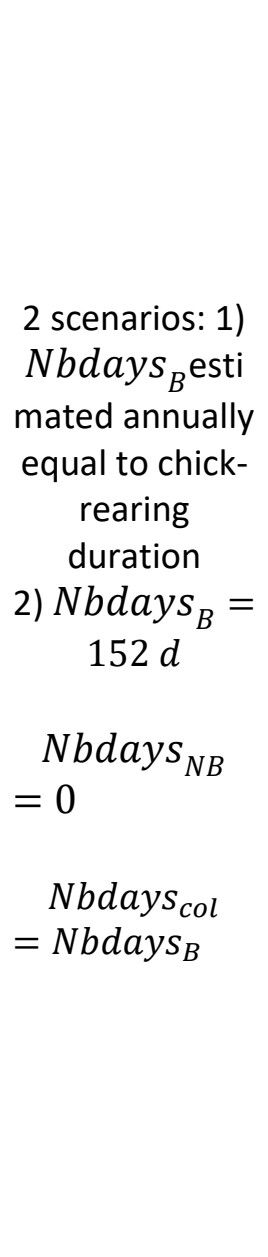 & $\begin{array}{l}\text { Meal size }=108 \\
\text { g.chick }{ }^{-1} \text {.day }^{-1} \text {, } \\
\text { (Øyan \& Anker- } \\
\text { Nilssen, 1996) } \\
\text { Nb of chicks } \\
\text { estimated from } \\
\text { counts }\end{array}$ & $\begin{array}{l}\text { Age } 0 \text { fraction } \\
\text { of the stock. } \\
\text { Estimated } \\
\text { using back- } \\
\text { calculations } \\
\text { from } \\
\text { recruitment } \\
\text { indices (i.e. } \\
\text { age class 3) } \\
\text { obtained } \\
\text { through VPA } \\
\text { (ICES, 2012; } \\
\text { Toresen \& } \\
\varnothing \text { stvedt, 2000) }\end{array}$ \\
\hline
\end{tabular}




\begin{tabular}{|c|c|c|c|c|c|c|c|c|}
\hline $\begin{array}{c}\text { Cape gannet in } \\
\text { the southern } \\
\text { Benguela }\end{array}$ & $\begin{array}{l}\text { Chick=Adult } \\
\text { diet } \\
\text { Annual values } \\
\text { (average from } \\
\text { all months and } \\
2 \text { localities) } \\
\text { (Crawford et } \\
\text { al., 2019) }\end{array}$ & $\begin{array}{l}0.74 \text { (Crawford, } \\
\text { Ryan, \& } \\
\text { Williams, 1991) }\end{array}$ & $\begin{array}{l}8.59 \text { and } 6.74 \\
\mathrm{kJ.g}^{-1} \text { for } \\
\text { sardine and } \\
\text { anchovy } \\
\text { respectively } \\
\text { (Batchelor \& } \\
\text { Ross, 1984) }\end{array}$ & 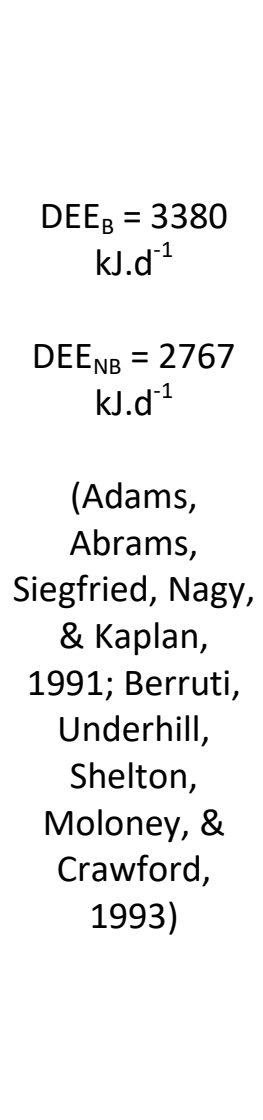 & $\begin{array}{l}\text { Lambert's Bay } \\
+ \text { Malgas Island } \\
\text { populations } \\
\text { (South Africa } \\
\text { west coast) } \\
\\
\mathrm{N}_{\mathrm{B}, \mathrm{t}} \text { estimated } \\
\text { from occupied } \\
\text { breeding area } \\
\text { sizes and } \\
\text { densities of } \\
\text { nests } \\
\text { (Crawford et } \\
\text { al., } 2007 \\
\text { updated) } \\
\\
\mathrm{N}_{\mathrm{NB}, \mathrm{t}}=\mathrm{nb} \text { of } \\
\text { immature from } \\
1 \text { to } 4 \\
\text { (estimated } \\
\text { from number } \\
\text { of chicks and } \\
\text { age-dependent } \\
\text { survival) }\end{array}$ & $\begin{array}{l}\text { Nbdays }_{B}= \\
\quad 165 . \\
\text { Nbdays }_{N B} \\
=140 \\
\text { Nbdays }_{\text {Col }} \\
\text { dependent on } \\
\text { age-class } \\
\text { (Jarvis, 1974) }\end{array}$ & $\begin{array}{c}\text { Nb of chicks }= \\
\text { nb of breeding } \\
\text { pairs } * 0.45 \\
\\
\mathrm{DEE}_{\text {chick }}=2236 \\
{\mathrm{~kJ} . \mathrm{d}^{-1} \text { (Cooper, }} \\
1978) \\
\\
\text { Nbdays }_{\text {chick }}=97 \\
\text { (Jarvis, } 1974)\end{array}$ & $\begin{array}{c}\text { Spawning } \\
\text { stock biomass } \\
\text { West of Cape } \\
\text { Agulhas } \\
\\
\text { Estimated } \\
\text { based on } \\
\text { hydro-acoustic } \\
\text { surveys } \\
\text { (Augustyn et } \\
\text { al., 2018; } \\
\text { Coetzee et al., } \\
\text { 2008) }\end{array}$ \\
\hline
\end{tabular}




\begin{tabular}{|c|c|c|c|c|c|c|c|c|}
\hline $\begin{array}{l}\text { Common } \\
\text { murre in the } \\
\text { Baltic Sea }\end{array}$ & $\begin{array}{l}\text { Chick = adult } \\
\text { diet } \\
\text { Annual values } \\
\text { (Kadin, } \\
\text { Österblom, } \\
\text { Hentati- } \\
\text { Sundberg, \& } \\
\text { Olsson, 2012) }\end{array}$ & $\begin{array}{c}\text { 0.78(Hilton, } \\
\text { Furness, \& } \\
\text { Houston, 2000) }\end{array}$ & $\begin{array}{c}5.46 \mathrm{~kJ} . \mathrm{g}^{-} \\
{ }^{1} \text { (Enekvist, } \\
2003 \text { ) }\end{array}$ & $\begin{array}{c}\mathrm{DEE}_{\mathrm{B}}=1530 \\
\mathrm{~kJ} \cdot \mathrm{d}^{-1} \\
\mathrm{DEE} \mathrm{NB}_{\mathrm{NB}}=1392 \\
\mathrm{~kJ} . \mathrm{d}^{-1} \\
\text { (Roth, Nur, } \\
\text { Warzybok, \& } \\
\text { Sydeman, } \\
\text { 2008) }\end{array}$ & $\begin{array}{c}\text { Entire Baltic } \\
\text { Sea population } \\
\mathrm{N}_{\mathrm{B}, \mathrm{t}}=100 / 65 * \\
\mathrm{~N}_{\mathrm{B}, \mathrm{t}} \text { at Stora } \\
\text { Karlsö } \\
(\mathrm{Olsson} \& \\
\text { Hentati- } \\
\text { Sundberg, } \\
2017) \text { from } \\
\text { annual counts } \\
\text { at Stora Karlsö } \\
\mathrm{N}_{\mathrm{NB}, \mathrm{t}}=0.5 * \mathrm{~N}_{\mathrm{B}, \mathrm{t}}\end{array}$ & $\begin{array}{l}\text { Nbdays }_{B}=90 \\
\text { (Hedgren, } \\
\text { 1975) } \\
\\
\text { Nbdays }_{N B} \\
=275 \\
\\
\text { Nbdays }_{C o l} \\
=365\end{array}$ & $\begin{array}{c}\text { Meal size }= \\
4 * 10.26=41 \\
\text { g.chick }{ }^{-1} \text {.day }{ }^{-1}, \\
\text { (Enekvist, } \\
\text { 2003; Kadin et } \\
\text { al., 2012) } \\
\\
\text { Nb of chicks = } \\
\text { annual } \\
\text { breeding } \\
\text { success * nb of } \\
\text { breeding pairs } \\
\text { (Kadin et al., } \\
\text { 2012) } \\
\text { Nb of days = } \\
\text { 18d (Kadin, } \\
\text { Olsson, } \\
\text { Hentati- } \\
\text { Sundberg, } \\
\text { Ehrning, \& } \\
\text { Blenckner, } \\
2016 \text { ) }\end{array}$ & $\begin{array}{l}\text { Spawning } \\
\text { Stock biomass } \\
\text { Entire baltic } \\
\text { Sea } \\
\text { Estimated } \\
\text { through XSA } \\
\text { using acoustics } \\
\text { and landings } \\
\text { as inputs } \\
\text { (ICES, 2018) }\end{array}$ \\
\hline
\end{tabular}




\begin{tabular}{|c|c|c|c|c|c|c|c|c|}
\hline $\begin{array}{l}\text { Shetland } \\
\text { Islands }\end{array}$ & $\begin{array}{c}\text { Chick = adult } \\
\text { diet } \\
\text { Period values } \\
\text { (Furness, 1990; } \\
\text { Furness \& } \\
\text { Tasker, 2000; } \\
\text { Martin, 1989) }\end{array}$ & $\begin{array}{l}0.80 \text { (Hilton et } \\
\text { al., 2000) }\end{array}$ & $\begin{array}{c}6 \mathrm{kJ.g}^{-1} \\
\text { (Pedersen \& } \\
\text { Hislop, 2001) }\end{array}$ & $\begin{array}{c}\mathrm{DEE}_{\mathrm{B}} \text { estimated } \\
\text { from allometric } \\
\text { equations per } \\
\text { order } \\
\\
\mathrm{DEE}_{\mathrm{NB}}=2.25 \\
\text { BMR } \\
\text { (Ellis \& } \\
\text { Gabrielsen, } \\
\text { 2002) }\end{array}$ & $\begin{array}{c}\text { Shetland } \\
\text { populations } \\
\\
\mathrm{N}_{\mathrm{B}, \mathrm{t}} \text { estimated } \\
\text { from counts } \\
\text { (Mitchell, } \\
\text { Newton, } \\
\text { Ratcliffe, \& } \\
\text { Dunn, 2004; } \\
\text { Walsh et al., } \\
1995 \text { ) } \\
\mathrm{N}_{\mathrm{NB}, \mathrm{t}}=25 \% \text { of } \\
\text { breeding birds }\end{array}$ & $\begin{array}{l}\text { Nbdays }_{B} \text { for } \\
\text { each species } \\
\text { (122d for great } \\
\text { skua, } 106 \text { for } \\
\text { arctic skua, } \\
\text { common murre } \\
\text { and razorbill, } \\
78 \text { artic tern, } \\
108 \text { puffin, 136 } \\
\text { kittiwake, great } \\
\text { blacked-back } \\
\text { gull, black } \\
\text { guillemot, } \\
\text { fulmar, shag } \\
\text { and gannet) } \\
\text { (Furness, 1990) } \\
\\
\text { Nbdays }_{N B}=0 \\
\text { Nbdays }_{\text {col }} \\
=\text { Nbdays }_{B}\end{array}$ & $\begin{array}{c}\text { Nb of chicks = } \\
\text { Breeding } \\
\text { success * nb of } \\
\text { breeding pairs } \\
\text { DEE from the } \\
\text { same equation } \\
\text { as non- } \\
\text { breeding adult } \\
\text { with } \mathrm{M}_{\text {chick }}= \\
0.5 \mathrm{M}_{\text {adult }} \\
\\
\text { Nb of days = } \\
\text { chick-rearing } \\
\text { duration }\end{array}$ & $\begin{array}{l}\text { Total biomass } \\
\text { Shetland stock } \\
\text { Estimated } \\
\text { from VPA } \\
\text { using landings } \\
\text { and } \\
\text { experimental } \\
\text { trawl surveys } \\
\text { as inputs }\end{array}$ \\
\hline
\end{tabular}




\begin{tabular}{|c|c|c|c|c|c|c|c|c|}
\hline $\begin{array}{l}\text { Northern } \\
\text { Humboldt }\end{array}$ & $\begin{array}{c}\text { Chick = adult } \\
\text { diet } \\
\text { Period values } \\
\text { (Goya, 2000; } \\
\text { Jahncke, } \\
\text { Checkley, \& } \\
\text { Hunt, 2004) }\end{array}$ & $\begin{array}{c}0.75 \text { (Dunn, } \\
\text { 1975; Laugksch } \\
\text { \& Duffy, 1984) }\end{array}$ & $\begin{array}{c}6.37 \text { kJ.g } \\
\text { (Cooper, 1978; } \\
\text { Laugksch \& } \\
\text { Duffy, 1984) }\end{array}$ & $\begin{array}{c}\mathrm{DEE}_{\mathrm{B}} \text { estimated } \\
\text { from allometric } \\
\text { equations of } \\
\text { pelecaniform } \\
\mathrm{DEE}_{\mathrm{NB}}=2.25 \\
\mathrm{BMR} \\
\text { (Ellis \& } \\
\text { Gabrielsen, } \\
\text { 2002) }\end{array}$ & $\begin{array}{c}\text { Entire } \\
\text { Northern } \\
\text { Humboldt } \\
\text { populations (31 } \\
\text { islands) } \\
\text { Monthly } \\
\text { counts of total } \\
\text { number of } \\
\text { birds. } \\
\mathrm{N}_{\mathrm{B}, \mathrm{t}} \text { and } \mathrm{N}_{\mathrm{NB}, \mathrm{t}} \\
\text { derived from } \\
\text { monthly } \\
\text { average } \\
\text { proportions of } \\
\text { breeders vs } \\
\text { non-breeders } \\
\text { based on the } \\
\text { 2003-2014 } \\
\text { observations. }\end{array}$ & $\begin{array}{c}\text { Nbdays }_{\text {col }}= \\
365 .\end{array}$ & $\begin{array}{c}\text { DEE from the } \\
\text { same equation } \\
\text { as non- } \\
\text { breeding adult } \\
\text { with } \mathrm{M}_{\text {chick }}= \\
0.5 \mathrm{M}_{\text {adult }} \\
\text { Nb chick = } \\
\text { brood size }{ }^{*} \text { nb } \\
\text { of breeding } \\
\text { pairs } \\
\text { Duration: } 86 \mathrm{~d}, \\
\text { 133d and } 110 \mathrm{~d} \\
\text { for cormorant, } \\
\text { booby and } \\
\text { pelican }\end{array}$ & $\begin{array}{l}\text { Production } \\
\text { biomass } \\
\text { Northern } \\
\text { Humboldt (7- } \\
18^{\circ} \text { S) from the } \\
\text { coast to } \\
\text { 100km } \\
\text { offshore } \\
\text { Estimated } \\
\text { from acoustic } \\
\text { estimates and } \\
\text { monthly } \\
\text { length } \\
\text { structure } \\
\text { (Oliveros- } \\
\text { Ramos \& } \\
\text { Peña, 2011) }\end{array}$ \\
\hline
\end{tabular}

Table 1. Main parameters and assumptions used in the estimation of seabird consumption in each ecosystem. 


\begin{tabular}{|c|c|c|c|c|c|}
\hline Variables & Ecosystem/Species & Model type & $\mathrm{AICc}$ & $\triangle \mathrm{AICc}$ & $\mathbf{n}$ \\
\hline \multirow{10}{*}{$\begin{array}{l}\text { Diet } \sim \text { Stock } \\
\text { biomass }\end{array}$} & \multirow{3}{*}{$\begin{array}{l}\text { Norwegian Sea - } \\
\text { Puffins - Age } 0 \\
\text { herring }\end{array}$} & null & 211.1 & 0 & \multirow{3}{*}{23} \\
\hline & & Logarithmic & 212.0 & 0.9 & \\
\hline & & Power & 212.3 & 1.2 & \\
\hline & \multirow{3}{*}{$\begin{array}{c}\text { Benguela - Gannets - } \\
\text { Sardines }\end{array}$} & Logarithmic & 253.4 & 0 & \multirow{3}{*}{37} \\
\hline & & Power & 254.0 & 0.6 & \\
\hline & & null & 324.9 & 71.5 & \\
\hline & \multirow{3}{*}{$\begin{array}{c}\text { Benguela - Gannets - } \\
\text { Anchovies }\end{array}$} & Power & 205.4 & 0 & \multirow{3}{*}{37} \\
\hline & & Logarithmic & 205.8 & 0.4 & \\
\hline & & null & 311.9 & 106.5 & \\
\hline & $\begin{array}{l}\text { Baltic Sea - Murres - } \\
\text { Sprats }\end{array}$ & null & 64.1 & 0 & 14 \\
\hline \multirow{13}{*}{$\begin{array}{l}\text { Consumption } \\
\text { Stock biomass }\end{array}$} & \multirow{3}{*}{$\begin{array}{l}\text { Norwegian Sea - } \\
\text { Puffins - Age } 0 \\
\text { herring }\end{array}$} & null & 445.8 & 0 & \multirow{3}{*}{22} \\
\hline & & $\begin{array}{l}\text { Type III } \\
\text { functional } \\
\text { response }\end{array}$ & 447.0 & 1.2 & \\
\hline & & $\begin{array}{l}\text { Type II } \\
\text { functional } \\
\text { response }\end{array}$ & 447.4 & 1.6 & \\
\hline & \multirow{5}{*}{$\begin{array}{l}\text { Benguela - Gannets - } \\
\text { Sardines }\end{array}$} & $\begin{array}{l}\text { Type II } \\
\text { functional } \\
\text { response }\end{array}$ & 590.8 & 0 & \multirow{5}{*}{31} \\
\hline & & $\begin{array}{l}\text { Type III } \\
\text { functional } \\
\text { response }\end{array}$ & 591.1 & 0.3 & \\
\hline & & Logarithmic & 591.4 & 0.6 & \\
\hline & & Power & 592.0 & 1.2 & \\
\hline & & null & 615.3 & 24.5 & \\
\hline & \multirow{5}{*}{$\begin{array}{c}\text { Benguela - Gannets - } \\
\text { Anchovies }\end{array}$} & $\begin{array}{l}\text { Type II } \\
\text { functional } \\
\text { response }\end{array}$ & 503.0 & 0 & \multirow{5}{*}{31} \\
\hline & & Power & 503.1 & 0.1 & \\
\hline & & $\begin{array}{l}\text { Type III } \\
\text { functional } \\
\text { response }\end{array}$ & 504.1 & 1.1 & \\
\hline & & Logarithmic & 504.3 & 1.4 & \\
\hline & & Linear & 504.6 & 1.7 & \\
\hline
\end{tabular}




\begin{tabular}{|c|c|c|c|c|}
\hline & null & 589.5 & 86.5 & \\
\hline \multirow{5}{*}{$\begin{array}{c}\text { Baltic Sea - Murres - } \\
\text { Sprats }\end{array}$} & Power & 230.9 & 0 & \multirow{5}{*}{14} \\
\hline & Logarithmic & 231.1 & 0.2 & \\
\hline & Exponential & 231.3 & 0.4 & \\
\hline & Linear & 231.5 & 0.6 & \\
\hline & null & 234.0 & 3.1 & \\
\hline \multirow{8}{*}{$\begin{array}{l}\text { Humboldt - All } 3 \\
\text { species - Anchovies }\end{array}$} & Power & 1374.4 & 0 & \multirow{8}{*}{48} \\
\hline & Logarithmic & 1374.6 & 0.2 & \\
\hline & $\begin{array}{l}\text { Type II } \\
\text { functional } \\
\text { response }\end{array}$ & 1374.8 & 0.4 & \\
\hline & Quadratic & 1374.9 & 0.5 & \\
\hline & Linear & 1374.9 & 0.5 & \\
\hline & Null & 1375.6 & 1.2 & \\
\hline & Exponential & 1375.6 & 1.2 & \\
\hline & $\begin{array}{l}\text { Type III } \\
\text { functional } \\
\text { response }\end{array}$ & 1376.46 & 2.0 & \\
\hline \multirow{2}{*}{$\begin{array}{l}\text { Norwegian Sea - } \\
\text { Puffins - Age } 0 \\
\text { herring }\end{array}$} & Power & 196.9 & 0 & \multirow{2}{*}{22} \\
\hline & null & 218.6 & 21.7 & \\
\hline \multirow{2}{*}{$\begin{array}{c}\text { Benguela - Gannets - } \\
\text { Sardines }\end{array}$} & Power & 135.8 & 0 & \multirow{2}{*}{31} \\
\hline & null & 155.0 & 19.2 & \\
\hline \multirow{2}{*}{$\begin{array}{c}\text { Benguela - Gannets - } \\
\text { Anchovies }\end{array}$} & Power & 39.2 & 0 & \multirow{2}{*}{31} \\
\hline & null & 74.3 & 35.2 & \\
\hline \multirow{3}{*}{$\begin{array}{l}\text { Baltic Sea - Murres - } \\
\text { Sprats }\end{array}$} & Power & -22.7 & 0 & \multirow{3}{*}{14} \\
\hline & Exponential & -21.6 & 1.1 & \\
\hline & null & 1.2 & 25.3 & \\
\hline \multirow{2}{*}{$\begin{array}{l}\text { Humboldt - All } 3 \\
\text { species - Anchovies }\end{array}$} & Power & 209.1 & 0 & \multirow{2}{*}{48} \\
\hline & null & 254.7 & 45.6 & \\
\hline
\end{tabular}

$\overline{\text { Table 2. Seabird diet and consumption according to prey biomass. Six a priori parametric models }}$ were fitted using non-linear least square adjustment (null model assuming no link of seabird diet or consumption with prey biomass, linear model assuming a constant increase of seabird diet or 
consumption with fish biomass, second-order polynomial models assuming an optimum fish biomass for seabirds, as well as exponential, logarithmic and power models which all assume non-linearities and some sort of thresholds above or below which seabirds react differently to prey). Additionally, functional responses of type II and III were also tested for the relationship between seabird consumption and prey biomass. Results of the most supported models ( $\triangle \mathrm{AICc} \leq 2)$ are presented along with the null model. Results are not presented in the Shetland system, where too few data points hindered quantitative analyses. Also, for the Humboldt, no model was performed on the diet data and consumption was estimated as the sum of the consumption made by the three seabird species. 


\section{Figures}

Figure 1. Ecosystems under study along with the studied seabird and fish species.

Figure 2. Schematics of the method used to quantify the proportion of a fish stock that is consumed by seabirds.

Figure 3. Trends in the annual contributions of the main fish prey to the diet of seabird species at Røst from 1982 to 2006 (Atlantic herring in puffin diet), in the Baltic Sea from 1985 to 1995 (sprat in murre diet), in the Northern Humboldt from 1961 to 2008 (anchovy in the diet of three bird species), on the west coast of South Africa from 1985 to 2011 (sardine and anchovy in gannet diet), and at Shetland in 1977, 1986 and 2000 (sandeel in the diet of 12 bird species).

Figure 4. Relationships between the stock biomass of prey (thousand tonnes) and the percentage contribution of prey to the diet of seabirds for each of the five ecosystems. As 12 seabird species were considered at Shetland, we present the mean \pm SE for that locality. When two variables were significantly related, dashed lines represent the fit of the best relationship between these variables (see Table 2). Note that for the Benguela, the two candidate models (i.e. $\Delta \mathrm{AIC} \leq 2$ ) gave very similar predictions, so that just one was plotted for clarity purposes.

Figure 5. Relationships between the stock biomass of prey (thousand tonnes) and the consumption of prey (thousand tonnes) by seabirds. When two variables were significantly related, dashed lines represent the fit of the best relationship between these variables (see Table 2). Note that for the Benguela and the Baltic, the different candidate models (i.e. $\Delta \mathrm{AIC} \leq 2$ ) gave very similar predictions, so that just one was plotted for clarity purposes.

Figure 6. Relationships between the stock biomass of prey (thousand tonnes) and the percentage of the stock consumed by seabirds. When two variables were significantly related, dashed lines represent the fit of the best relationship between these variables (see Table 2). The thresholds in the 
non-linear relationships between stock biomass and the percentage of the stock consumed by seabirds were calculated from change-point analyses and are indicated by vertical solid lines, while the median stock biomass is indicated by a dashed vertical line. Note that for the Baltic, the different candidate models (i.e. $\Delta \mathrm{AIC} \leq 2$ ) gave very similar predictions, so that just one was plotted for clarity purposes.

Figure 7. Relationships between fish stock biomass at year $t$ and the number of seabirds (in thousands) present at year t-1 (left) or the percentage of the stock consumed by seabirds at year t-1 (middle). To account for autocorrelation in the Benguela and Humboldt ecosystems, the stock biomass at $\mathrm{t}-1$ was added as an explanatory variable in all 6 models run for these two ecosystems. Lines depicting the relationships are drawn in the case of significant relations (linear model with the stock biomass at t-1 as a co-variable). On the right are represented the relationships between the change in fish stock biomass from year $\mathrm{t}-1$ to year $\mathrm{t}$ and the percentage of the stock consumed by seabirds at year t-1. Such analyses were not considered for the Norwegian Sea ecosystem, as puffins there consume age 0 herring, which reach maturity at age 3, nor for Shetland were seabirds were not monitored on an annual basis. 


\section{Supplementary material}

\section{ESM1: Methods: details on data collection in each ecosystem}

\section{Atlantic puffin at Røst}

Puffin chick diet was available for all years 1982-2006, except for 1987 and 1995, from (AnkerNilssen \& Aarvak, 2006) and unpublished data of SEAPOP (www.seapop.no/en, the Norwegian seabird program). Further, because there appears to be no significant differences in the diet of chicks and adults (Albertsen, 1996) chick diet was used to estimate the proportional contribution by mass of herring Clupea harengus of age zero regardless of puffin life stages. Calorific values of the main prey (3.7 kJ.g ${ }^{-1}$ wet mass for age 0 herring; Anker-Nilssen \& Øyan, 1995) enabled us to calculate the proportional contribution by energy of age 0 herring in the diet, i.e. $P_{t}$. Assimilation efficiency was set at $70 \%$ as recommended for prey this lean (Brekke \& Gabrielsen, 1994).

Daily energy expenditure of breeding puffins was entered at $848 \mathrm{~kJ} \cdot \mathrm{d}^{-1}$ as reported from a study in another Norwegian colony (Barrett, Gabrielsen, \& Fauchald, 1995; Ellis \& Gabrielsen, 2002) for the same average adult body mass as at Røst (460 g, Barrett et al., 1995). Given the general lack of empirical data on FMR for non-breeding auks, we conservatively set $D E E_{N B}$ at two times the basal metabolic rate (BMR), which is about three quarters of the FMR/BMR ratio of 2.7 reported for

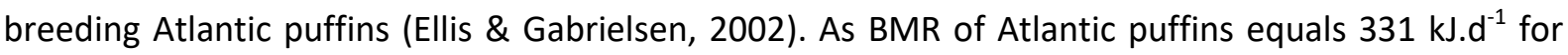

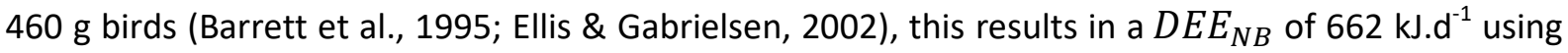
average body mass at Røst, i.e. a decrease of $22 \%$ in DEE compared to breeding birds.

The number of Atlantic puffins breeding at Røst in year $\mathrm{t}, N_{B, t}$, as calculated using the method developed by (Anker-Nilssen \& Røstad, 1993) and applied to all the islands as reported by (AnkerNilssen \& Øyan, 1995) was available for all years 1982-2012 (Anker-Nilssen \& Aarvak, 2006; unpublished data of SEAPOP). We estimated non-breeders on site (i.e. immature and adults skipping reproduction) by assuming that mean age at first breeding is 5 to 7 years (Anker-Nilssen \& Aarvak, 2006). Birds at each age class from 1 to 5 were thus considered immature and their numbers 
estimated from cohort survival rates, given a constant survival rate of $75 \%$ in their first year of life and an immature survival thereafter equal to that of breeding birds (Sandvik, Erikstad, Fauchald, \& Tveraa, 2008). As most 1-year old birds do not visit the colony (Sandvik et al., 2008), we excluded this class of immature birds from our calculations. Finally, we assumed that $25 \%$ of mature adults skip reproduction or fail before hatching.

As puffins are present on Røst only during the breeding season, Nbdays $_{N B}$ was considered to be null and $\mathrm{Nbdays}_{\text {col }}=\mathrm{Nbdays}_{B}$. Further, age 0 herring are known to be a key prey for these puffins during the chick-rearing period (Albertsen, 1996; Anker-Nilssen, 1992; Anker-Nilssen \& Aarvak, 2006). However, little data on diet is available outside this time window. Due to this uncertainty, we considered a precautionary approach based on the use of two extreme scenarios, where the number of days spent in the colony feeding on age 0 -herring was minimum and maximum, in order to have a range of consumption estimation. First, in the minimum consumption scenario, the period considered was restricted to chick-rearing, so that $\operatorname{Nbdays}_{N B}=0$ and $\operatorname{Nbdays}_{\text {col }}=\operatorname{Nbdays}_{B}=$

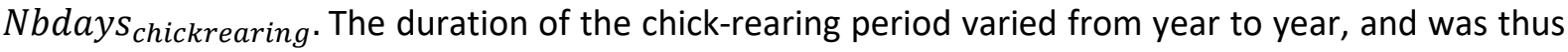
estimated annually. The second scenario considered the maximum time spent by puffins in the area. Indeed, although no diet study confirmed a direct link, some indications of the impact of age 0 herring abundance on puffin condition prior to egg-laying have been highlighted (Barrett, AnkerNilssen, Gabrielsen, \& Chapdelaine, 2002; Barrett, Nilsen, \& Anker-Nilssen, 2012). In order to account for this pre-laying period, the calculation started from $1^{\text {st }}$ of May. Then a few studies also support the assumption of herring consumption beyond the breeding season (see (Gimenez, Anker-Nilssen, \& Grosbois, 2012) for the effect of age 0 herring abundance on adult survival and (Anker-Nilssen \& Aarvak, 2009; Fayet et al., 2017) on post-breeding movements by telemetry and geolocators). The calculation thus included August and September, so that the entire duration was set to 152 days.

Chick's consumption was calculated directly from meal size and feeding rates (108 g.chick ${ }^{-1}$.day ${ }^{-1}$; Øyan \& Anker-Nilssen, 1996) and the annual number of chicks estimated through counts of active nests. 
Because breeding puffins in Røst do not feed on herring older than age 0 , which stay out of reach in the nursery areas in the SE Barents Sea before becoming too large as prey for puffins, we used the biomass of age 0 herring to estimate the proportion consumed (Toresen $\& \varnothing$ stvedt, 2000). The biomass of age 0 herring arriving at their nursery grounds in the Barents Sea a few months later was not directly derived from spawning stock size, as this relationship seems weak for the Norwegian spring-spawning stock (Toresen \& Østvedt, 2000). Rather it was estimated for all years up to 2011 from back-calculation in virtual population analysis (VPA) from recruitment indices (i.e. age class 3 ) assuming a fixed larval mortality rate (ICES, 2012). This enabled the proportion of the biomass consumed by Atlantic puffins during the nestling period to be estimated for all 23 years that had information on the contribution of herring to the diet of puffins. It should be noted that the true proportions consumed by puffins in the nestling period were most likely overestimated, as the actual biomass of age 0 herring drifting past the colony in the nestling period was probably significantly higher to an unknown extent (P. Fossum, Norwegian Institute of Marine Research, pers. comm.). As the day-to-day survival of drifting age 0 herring during summer is not known in detail, this bias is difficult to account for.

\section{Cape gannet in the southern Benguela ecosystem}

Cape gannets are one of the seabirds in the Benguela ecosystem that subsist mainly on sardine and anchovy (Berruti, Underhill, Shelton, Moloney, \& Crawford, 1993). They breed at three localities in Namibia, and at three in South Africa, of which two, Lambert's Bay and Malgas Island, are off South Africa's west coast (Berruti et al., 1993). This study focuses on these two colonies.

The average proportional contribution by mass of five prey categories: sardine, anchovy, saury, Cape hake and other, was available for Cape gannets off western South Africa for 1978-2014 from information in (Crawford, Sydeman, Thompson, Sherley, \& Makhado, 2019). The proportional contribution by energy of each of these prey categories was then calculated from the calorific content of prey category i in $\mathrm{kJ}^{-g^{-1}}$ (values from (Batchelor \& Ross, 1984): sardine 8.59, anchovy 6.74, 
saury 6.20 , hakes 4.07 and other $5.60 \mathrm{~kJ}^{-1} \mathrm{~g}^{-1}$. Details on the sampling method can be found in (Crawford et al., 2019). The assimilation efficiency was set at $74 \%$ according to a previous study (Crawford, Ryan, \& Williams, 1991). The daily energy expenditure of a breeding Cape gannet (DEE $\mathrm{B}_{\mathrm{B}}$ ) is

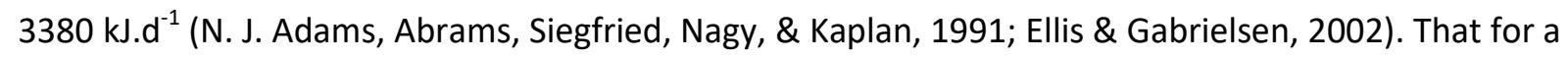
non-breeding Cape gannet $\left(D_{E E}\right.$ ) was taken to be $2767 \mathrm{~kJ} \cdot \mathrm{d}^{-1}$ based on a similar contribution of prey species to the diet but an $18 \%$ smaller meal size for non-breeding than breeding Cape gannets at Malgas Island (Berruti et al., 1993).

Numbers of Cape gannets breeding at Lambert's Bay and Malgas Island in year $t\left(\mathrm{~N}_{B, t}\right)$ were available for 1978-2014 from information in (Crawford et al., 2007) updated. We assumed that all mature birds breed at some point during the year, so that non-breeders come down to immatures only, i.e. birds of age 1 to 4 (Crawford, 1999). Numbers at each age class, from 1 to 4 , were estimated by following cohorts, using the number of chicks in each year and age-dependent survival. Cape gannets in their first two years (aged 0 and 1 years) have a mean annual survival of 0.71 (Crawford, 1999) and thereafter birds along western South Africa have an average adult survival of 0.86 (Distiller, Altwegg, Crawford, Klages, \& Barham, 2012).

The proportion of a year that birds of different ages remained in western South Africa was estimated from the proportion of recoveries and resightings of banded birds that occurred within $400 \mathrm{~km}$ of a breeding colony (Klages, 1994) as follows: < 1 year old $40 \% ; 1-2$ years old $44 \%$, 3 years old $70 \%,>4$ years old $100 \%$ of the breeding period and $70 \%$ of the non-breeding period. The breeding season of Cape gannets lasts c. 165 days, c. 150 days for incubation and chick rearing (Jarvis, 1974) plus c. 15 days for pairing and nest building, so that the non-breeding season is about 200 days.

Finally, chick number was estimated through the number of breeding pairs and breeding success. Over 17 seasons at Lambert's Bay and 22 at Malgas Island between 1988 and 2010 Cape gannets had a mean annual breeding success of 0.45 chicks per pair (Cury et al., 2011). Chicks spend on average 97 days at nests before fledging (Jarvis, 1974). The average daily energy requirement of chicks that fledge is $2236 \mathrm{~kJ}^{-1} \mathrm{~d}^{-1}$ (Cooper, 1978). 
Estimates for the two localities were summed to obtain an overall amount of consumption by Cape gannets breeding on the west coast in tonnes. Cape gannets at Lambert's Bay and Malgas Island forage offshore of Lambert's Bay to the west of Cape Agulhas when breeding (Pichegru et al., 2007). Estimates of the biomass of sardine and anchovy to the west of Cape Agulhas were available for each year from 1985-2014, based on hydro-acoustic surveys undertaken from late October to early December, centered in November (Augustyn et al., 2018; Coetzee et al., 2008).

\section{Common murre in the Baltic Sea}

Adult and juvenile common murre in the Baltic Sea feed predominately on sprat, with limited options for prey switching. Previous studies have estimated percentages of sprat in the adult and chick diet to be higher than $90 \%$, whether in mass or numbers (Hedgren, 1976; Lyngs \& Durinck, 1998; Österblom \& Olsson, 2002). In this study, the \% in mass was estimated for the 2002-2015 period (Kadin, Österblom, Hentati-Sundberg, \& Olsson, 2012; HÖ and JHS unpublished monitoring data). This percentage was really high (between 92 and $99 \%$ ), the rest being a few three-spined sticklebacks Gasterosteus aculeatus and sandeels Ammodytes spp. Sprat and small herring are extremely difficult to distinguish in the field, and this (and previous) studies may have underestimated the potential contribution of herring in the diet. This may have led to an overestimation of the sprat consumption in the analysis. Data on species proportions in the diet were available for all years except 2003; for that year, the average for 2002 and 2004 was used.

The assimilation efficiency was taken as $78 \%$, the true metabolisable energy coefficient estimated for this species elsewhere (Hilton, Furness, \& Houston, 2000). We assumed an energy density for sprat of $5.46 \mathrm{~kJ} . \mathrm{g}^{-1}$ wet mass (Enekvist, 2003). Using previously published estimates of the energy requirements of common murres from the Arctic (Ellis \& Gabrielsen, 2002) and California (Roth, Nur, Warzybok, \& Sydeman, 2008), we estimated the average daily energy expenditure for non-breeders to be $1392 \mathrm{~kJ} . \mathrm{d}^{-1}$ and for breeders to be $1530 \mathrm{~kJ} \cdot \mathrm{d}^{-1}$. 
The population of common murres in the Baltic Sea was 13 000-17 000 pairs, of which approximately 65\% breed at Stora Karlsö (Olsson \& Hentati-Sundberg, 2017). Numbers of pairs breeding at Stora Karlsö were estimated annually during 2002-2015 based on direct observations. These numbers were doubled and multiplied by $100 / 65$ to estimate the total number of common murres breeding in the Baltic Sea in year $t\left(N_{B, t}\right)$. We assumed that the number of non-breeders in the population was equivalent to $50 \%$ of numbers breeding (i.e. $1 / 3$ of the entire population), based on observations at the Stora Karlsö colony and unpublished modeling results that indicate a high pre-breeding survival and a high proportion of non-breeding birds in the population. The length of the breeding season was set to 90 days, representing the period from the stabilization of the presence of the breeding population in late April to the departure in mid-late July (Hedgren, 1975).

Regarding chick consumption, it was estimated using a combination of number of chicks, number of days feeding, number of feeding events per day and chick meal size. The number of chicks was estimated based on annual monitoring of breeding success, which varied between 0.67 and 0.86 (Kadin et al., 2012; updated), and the number of breeding pairs. Data were not available for $2002-$ 2004 , so for these years the average for the whole time series $2005-2015$ was used. The number of days during which chicks are fed was set to $18 \mathrm{~d}$ (Kadin, Olsson, Hentati-Sundberg, Ehrning, \& Blenckner, 2016), while the meal size was estimated from the number of fish fed per day (4; Kadin et al., 2012) and the average weight of fish fed (0.01026kg; Enekvist, 2003).

We used estimates of sprat biomass for the entire Baltic Sea as determined by ICES (International Council for the Exploration of the Seas) through XSA (Extended Survival Analysis) which uses a combination of reported landings and acoustic surveys as input data (ICES, 2018). In this model, $M$ is calculated through a model (SMS, Stochastic Multi-Species model) using cod predation as timevarying factor. Seabirds are not included in the M estimate. Because bird consumption is so low in this ecosystem, using fisherman catch or fisherman + seabird catch in the catch equation should not 
change any result in biomass estimates $\left(C_{t}=7021 \pm 891\right.$ vs. Catches $=326,200 \pm 62,682$ tonnes, i.e. 46 times less consumption than catches).

\section{Seabirds at Shetland}

Several seabird species breed sympatrically in Shetland. In order to estimate the predation pressure exerted on fish stocks, we estimated the consumption of the entire seabird population, by working on 12 species: 9 charadriiforms (Great and Arctic skua Stercorarius skua and S. parasiticus, Arctic tern Sterna paradisaea, black-legged kittiwake Rissa tridactyla, great black-backed gull Larus marinus, black guillemot Cepphus grylle, razorbill Alca torda, common murre, Atlantic puffin), 1 procellariform (northern fulmar Fulmarus glacialis), and 2 pelecaniforms (northern gannet M. bassanus and European shag Phalacrocorax aristotelis).

Diet composition data were collected either as voluntary regurgitates by chicks or adults handled for ringing (great skua, Arctic skua, northern fulmar, black-legged kittiwake, northern gannet and shag), or as cast pellets found near nests (great skua, great black-backed gull and shag), or as fish observed or photographed being carried by adults or sampled from birds caught by mist net, hand net, or noose and pole (Arctic tern, common murre, black guillemot, razorbill and Atlantic puffin). Diet sampling was primarily conducted at Foula, where samples were obtained annually from 1975 to 2004, except for gannets which were sampled only in a few years from Hermaness. Data on gannet diet from (Martin, 1989) were included to supplement unpublished data on gannet diet collected during ringing at the Hermaness colony. Diet sampling spanned both the incubation and chickrearing periods, but with larger numbers of samples during chick-rearing. Because sample sizes in individual years were not always large and because comprehensive seabird population censuses were only available for three time periods, for estimation of sandeel consumption diet, data were amalgamated for the periods $1975-1983,1984-1989$ and 2000-2004 and related to population sizes in 1977, 1986 and 2000. Diet data for 1975-1983 were previously reported in (Furness, 1990) and for 1990-1996 in (Furness \& Tasker, 2000). We assumed the proportion in terms of energy to be the 
same as the proportion in mass, as most items in the diet would be likely to be similar in energy content to sandeels (slightly higher for herring and mackerel, slightly lower for whiting and haddock) and the difference between prey taxa likely to be no higher than the seasonal or interannual variability in sandeel energy content.

An assimilation efficiency of $80 \%$ was assumed (Hilton et al., 2000), and a calorific content of $6 \mathrm{~kJ}^{-1} \mathrm{~g}^{-1}$ for sandeels (Pedersen \& Hislop, 2001). Daily energy expenditure of breeding birds was estimated from data on body mass presented in (Furness, 1990) and the bioenergetics equations of (Ellis \& Gabrielsen, 2002) estimating field metabolic rate of breeding birds for each order (i.e. DEE = $11.49 * \mathrm{~m}^{0.718}$ for charadriiforms, DEE $=22.06^{*} \mathrm{~m}^{0.594}$ for procellariforms and DEE $=3.9 * \mathrm{~m}^{0.871}$ for pelecaniforms). Similarly, $D E E_{N B}$ was estimated as 2.25 times the basal metabolic rate (BMR), where BMR was estimated through allometric equations per order according to (Ellis \& Gabrielsen, 2002) (i.e. $B M R=2.149 * m^{0.804}$ for charadriiforms, $B M R=2.763 * m^{0.726}$ for procellariforms and $B M R=$ $1.392 * m^{0.823}$ for pelecaniforms).

Numbers of each seabird species breeding at Shetland were taken from surveys using standard census methods (Mitchell, Newton, Ratcliffe, \& Dunn, 2004; Walsh et al., 1995). Data were converted from census units to equivalent numbers of breeding pairs (Mitchell et al., 2004), and tabulated for 1977, 1986, and 2000. Additionally, we assumed that non-breeders (i.e. immature birds and mature adults that skip reproduction) represented a further addition of $25 \%$ to the breeders.

For seabirds that are only present in Shetland for a short period in spring and summer, dates of arrival and departure were taken from (Furness, 1990). For seabirds remaining in Shetland for longer, we assumed that sandeels were eaten only between 1 April and 15 August, since sandeels tend to remain within the sand at other times of year and are largely unavailable to seabirds, although common murres and shags may sometimes dig sandeels out of the sand during winter. 
Regarding chick consumption, the number of chicks was estimated by multiplying the number of breeding pairs by the species-specific breeding success in each of the 3 periods. The average DEE of chicks was then derived from the same equation as for adults, considering the average chicks' weight was half that of adults. Finally, the number of days used to estimate chick consumption corresponded to chick rearing duration.

Estimates of Shetland sandeel total stock biomass on $1^{\text {st }}$ of July each year were obtained by VPA combined with fishery-independent experimental trawl surveys (Wright \& Bailey, 1992). In this model, $M$ estimate is not a constant but is re-estimated each year based on diet composition and key predator abundance using a multispecies model. Still, while predator consumption includes that of seabirds and marine mammals, the most important predators of sandeels by far are fish - especially mackerel, herring, cod, haddock, whiting, and gurnard. Because predator consumption is included in $\mathrm{M}$, the catch equation should not include seabird consumption. Abundance in 1977 (123000 tonnes) was similar to that in 1976 and 1978 (103 000 and 106000 tonnes). Abundance in 1986 was lower (65 000 tonnes) but similar to 1985 and 1987 (76 000 and 36000 tonnes). Abundance in 2000 (15000 tonnes) was similar to that in 1999 and 2001 (25 000 and 17000 tonnes), considerably lower than in 1986, and an order of magnitude lower than in 1977.

\section{Seabirds in the Humboldt ecosystem}

Adult and juvenile Peruvian boobies, Guanay cormorants and Peruvian pelicans feed predominantly on anchovies. Owing to their greater diving capacity, Guanay cormorants are also able to feed on demersal species, while shallower-foraging boobies and pelicans are more restricted to the surface.

Diet was estimated through stomach content samplings and analysis of otoliths collected within rejection pellets (cormorants) along the period 1974-2008. As sampling could not be performed 
every year at each of the 31 islands and headlands used for breeding (Passuni et al., 2015), some assumptions had to be made. In particular, four types of periods were distinguished: (i) during strong El-Niño periods $(1973,1983,1998)$, when small pelagic populations are highly impacted, the proportion of anchovy in the diet was estimated to be $55 \%$ for the Guanay cormorant and $58 \%$ for boobies and pelicans (Goya, 2000), (ii) during sardine-favoured periods (1974-1982, 1984-1990), the proportion of anchovy in the diet was set to $80 \%$ for all three species (Jahncke, Checkley, \& Hunt, 2004), (iii) during anchovy-favoured periods and when fishing was regulated (1991-1997, 1999-2008), the proportion of anchovy in the diet was fixed to $81 \%$ for cormorants and $93 \%$ for boobies and pelicans (Goya, 2000), (iv) during anchovy-favoured periods and when fishing was not regulated (1961-1972), the proportion of anchovy in the diet was fixed to 70\% for all three species (Jahncke et al., 2004). Because no detailed data were available on the rest of diet, we assumed the proportion in terms of energy to be the same as the proportion in mass. Indeed, the second prey for these seabirds are sardines, a very closely related species.

Finally, an assimilation efficiency of $75 \%$ was assumed (Dunn, 1975; Laugksch \& Duffy, 1984) and a calorific content of $6.37 \mathrm{kJ.g}^{-1}$ for anchovies (Cooper, 1978; Laugksch \& Duffy, 1984).

Daily energy expenditure of breeding birds was estimated from data on average body mass and the bioenergetics equations of (Ellis \& Gabrielsen, 2002) estimating field metabolic rate for pelecaniforms $\left(D E E=3.9 * \mathrm{~m}^{0.871}\right)$. This resulted in an estimation of $3074 \mathrm{~kJ} \cdot \mathrm{d}^{-1}$ for Guanay cormorant, $2353 \mathrm{~kJ} . \mathrm{d}^{-1}$ for Peruvian booby and $6753 \mathrm{~kJ}^{-\mathrm{d}^{-1}}$ for Peruvian pelican. Similarly, daily energy expenditure of non-breeding birds was estimated as 2.25* BMR, BMR being obtained from the allometric equation $\mathrm{BMR}=1.392 * \mathrm{~m}^{0.823}$ valid for pelecaniforms (Ellis \& Gabrielsen, 2002), giving values comparable to what had previously been used.

Numbers of individuals of the three species were derived from counts made monthly on the 31 islands and headlands used for breeding by AGRORURAL over the 1961-2014 period. Even if breeding 
synchrony exists in this area (Passuni et al., 2015), the phenological patterns are not as sharp as in temperate region, and a small fraction of birds may breed any month of the year. Also, breeding seasonality was showed to change over the long term, at least for cormorants and pelicans, according to the regime shifts of the Humboldt Current System (Passuni et al., 2018). As a consequence, we used monthly counts to estimate the energy needed for the colony each month before summing it over the year. Based on the 2003-2014 period, when breeding and non-breeding birds were distinguished in the counts, we estimated the average proportion of breeders across the year to be $24 \%$ [21-31\%] for guanay cormorants, $21 \%$ [14-28\%] for boobies and $25 \%$ [19-38\%] for pelicans. These proportions were then applied to the 1961-2002 period.

The three species are resident in the North Humboldt Current System and were thus assumed to consume prey all-year round $\left(\right.$ Nbdays $\left._{c o l}=365\right)$. Breeding period duration $\left(\right.$ Nbdays $\left._{B}\right)$ was respectively set to 142, 203 and 161 days for cormorant, booby and pelican (Nelson, 2005; Tovar \& Cabrera, 2005).

Regarding chick consumption, the number of chicks was estimated by multiplying the number of breeding pairs to the mean species-specific brood size $(2.19,1.87$ and 1.99 respectively for cormorant, booby and pelican; S. Bertrand et al., 2012; Nelson, 2005). The average DEE of chicks was then derived from the same equation as for non-breeding adults assuming the average chicks' weight was half that of adults (S. Bertrand et al., 2012). Finally, the number of days used to estimate chick consumption corresponded to the sum of chick rearing duration and post-fledging duration $(86,133$ and 110 respectively for cormorant, booby and pelican).

We used anchovy production from an integrated assessment model (Oliveros-Ramos \& Peña, 2011) as a measure of potential anchovy abundance available to seabirds and the fishery. Anchovy production is the increase in population biomass due to somatic growth and birth rate 
without considering natural and fishing mortality and was estimated at monthly time steps. Anchovy production was built using acoustic estimates of biomass and anchovy length structure from scientific surveys and fishery landings between $7^{\circ}$ and $18^{\circ} \mathrm{S}$ and from the coast to $100 \mathrm{~km}$ offshore. In the model, $\mathrm{M}$ is set as constant $\left(\mathrm{M}=0.7 \mathrm{yr}^{-1}\right)$ based on the estimations made by Imarpe of 0.6 to 0.8 for the years 1974 and 2010. Adjusting the catch equation with bird consumption instead of just fishermen catches should not change much the stock assessment results, as catches are an order of magnitude higher than seabird consumption $\left(C_{t}=472,489 \pm 390,792\right.$ vs. Catches $=5,199,381$ $\pm 342,858$, i.e. 11 times less consumption than catches).

\section{References}

Adams, N. J., Abrams, R. W., Siegfried, W. R., Nagy, K. A., \& Kaplan, I. R. (1991). Energy expenditure and food consumption by breeding Cape gannets Morus capensis. Marine Ecology Progress Series, Vol. 70, pp. 1-9. doi: 10.2307/24816793

Albertsen, J. (1996). Food choice of breeding Puffins Fratercula arctica revealed by stable isotope analysis. University of Trondheim, Norway.

Anker-Nilssen, T. (1992). Food supply as a determinant of reproduction ans population development in Norwegian Puffins Fratercula arctica. Trondheim.

Anker-Nilssen, T., \& Aarvak, T. (2006). Anker-Nilssen, T., \& Aarvak, T. (2006). Long-term studies of seabirds in the municipality of Røst, Nordland. Results with focus on 2004 and 2005. Trondheim.

Anker-Nilssen, T., \& Aarvak, T. (2009). Satellite telemetry reveals post-breeding movements of Atlantic puffins Fratercula arctica from Røst, North Norway. Polar Biology, 32(11), 1657-1664. doi: 10.1007/s00300-009-0665-7

Anker-Nilssen, T., \& Øyan, H. S. (1995). Long-term studies of the breeding biology of puffins at Røst.

Anker-Nilssen, T., \& Røstad, O. W. (1993). Census and Monitoring of Puffins Fratercula arctica on Rost, N Norway, 1979-1988. Ornis Scandinavica, 24(1), 1. doi: $10.2307 / 3676402$

Augustyn, J., Cockroft, A., Kerwath, S., Lamberth, S., Githaigi-Mwicigi, J., Pitcher, G., ... Auerswald, I. (2018). South Africa. In B. F. Phillips \& M. Perez-Ramirez (Eds.), Climate change impacts in fisheries and aquaculture: a global analysis (pp. 479-522). John Wiley and Sons Inc.

Barrett, R. T., Anker-Nilssen, T., Gabrielsen, G. W., \& Chapdelaine, G. (2002). Food consumption by seabirds in Norwegian waters. ICES Journal of Marine Science, 59(1), 43-57. doi: 10.1006/jmsc.2001.1145

Barrett, R. T., Gabrielsen, G. W., \& Fauchald, P. (1995). Prolonged incubation in the Atlantic puffin (Fratercula arctica) and evidence of mild hypothermia as an enegry-saving mechanisms. In H. R. Skojdal, C. Hopkins, K. E. Erikstad, \& H. P. Leinaas (Eds.), Ecology of fjords and coastal waters (pp. 479-488). Amsterdam: Elsevier Science.

Barrett, R. T., Nilsen, E., \& Anker-Nilssen, T. (2012). Long-term decline in egg size of Atlantic 
puffins Fratercula arctica is related to changes in forage fish stocks and climate conditions. Marine Ecology Progress Series, 457, 1-10. doi: 10.3354/meps09813

Batchelor, A. L., \& Ross, G. J. B. (1984). The diet and implications of dietary change of Cape Gannets on Bird Island, Algoa Bay. Ostrich, 55(2), 45-63. doi: 10.1080/00306525.1984.9634757

Berruti, A., Underhill, L. G., Shelton, P. A., Moloney, C., \& Crawford, R. J. M. (1993). Seasonal and Interannual Variation in the Diet of Two Colonies of the Cape Gannet (Morus capensis) between 1977-78 and 1989. Colonial Waterbirds, 16(2), 158. doi: $10.2307 / 1521434$

Bertrand, S., Joo, R., Arbulu Smet, C., Tremblay, Y., Barbraud, C., \& Weimerskirch, H. (2012). Local depletion by a fishery can affect seabird foraging. Journal of Applied Ecology, 49(5), 1168-1177. doi: 10.1111/j.1365-2664.2012.02190.x

Brekke, B., \& Gabrielsen, G. (1994). Assimilation efficiency of adult Kittiwakes and Brunnich's Guillemots fed Capelin and Arctic Cod. Polar Biology, 14(4), 279-284. doi: 10.1007/BF00239177

Coetzee, J., Merkle, D., de Moor, C., Twatwa, N., Barange, M., \& Butterworth, D. (2008). Refined estimates of South African pelagic fish biomass from hydro-acoustic surveys: quantifying the effects of target strength, signal attenuation and receiver saturation. African Journal of Marine Science, 30(2), 205-217. doi: 10.2989/AJMS.2008.30.2.1.551

Cooper, J. (1978). Energetic Requirements for Growth and Maintenance of the Cape Gannet (Aves; Sulidae). Zoologica Africana, 13(2), 305-317. doi: 10.1080/00445096.1978.11447631

Crawford, R. J. M. (1999). Seabird responses to long-term changes of prey resources off southern Africa. In N. Adams \& R. Slotow (Eds.), Proceedings of 22nd International Ornithological Congress (pp. 688-705). Durban: BirdLife South Africa.

Crawford, R. J. M., Dundee, B. L., Dyer, B. M., Klages, N. T. W., Meÿer, M. A., \& Upfold, L. (2007). Trends in numbers of Cape gannets (Morus capensis), 1956/1957-2005/2006, with a consideration of the influence of food and other factors. ICES Journal of Marine Science, 64(1), 169-177. doi: 10.1093/icesjms/fsl011

Crawford, R. J. M., Ryan, P. G., \& Williams, A. J. (1991). Seabird consumption and production in the Benguela and Western Agulhas ecosystems. South African Journal of Marine Science, 11(1), 357-375. doi: 10.2989/025776191784287709

Crawford, R. J. M., Sydeman, W. J., Thompson, S. A., Sherley, R. B., \& Makhado, A. B. (2019). Food habits of an endangered seabird indicate recent poor forage fish availability off western South Africa. ICES Journal of Marine Science, 76(5), 1344-1352. doi: 10.1093/icesjms/fsz081

Cury, P. M., Boyd, I. L., Bonhommeau, S., Anker-Nilssen, T., Crawford, R. J. M., Furness, R. W., ... Sydeman, W. J. (2011). Global Seabird Response to Forage Fish Depletion--One-Third for the Birds. Science, 334(6063), 1703-1706. doi: 10.1126/science.1212928

Distiller, G., Altwegg, R., Crawford, R., Klages, N., \& Barham, B. (2012). Factors affecting adult survival and inter-colony movement at the three South African colonies of Cape gannet. Marine Ecology Progress Series, 461, 245-255. doi: 10.3354/meps09807

Dunn, E. H. (1975). Caloric Intake of Nestling Double-Crested Cormorants. The Auk, 92(3), 553-565. doi: 10.2307/4084609

Ellis, H. I., \& Gabrielsen, G. (2002). Energetics of free-ranging seabirds. In E. Schreiber \& J. Burger (Eds.), Biology of marine birds (pp. 359-407).

Enekvist, E. (2003). Energy intake of Common Guillemot, Uria aalge, chicks at Stora Karlsö, 
Sweden : influence of changes in the Baltic Sea. Retrieved from http://www.divaportal.org/smash/record.jsf?pid=diva2\%3A279689\&dswid=page

Fayet, A. L., Freeman, R., Anker-Nilssen, T., Diamond, A., Erikstad, K. E., Fifield, D., ... Guilford, T. (2017). Ocean-wide Drivers of Migration Strategies and Their Influence on Population Breeding Performance in a Declining Seabird. Current Biology, 27(24), 38713878.e3. doi: 10.1016/J.CUB.2017.11.009

Furness, R. (1990). A preliminary assessment of the quantities of Shetland sandeels taken by seabirds, seals, predatory fish and the industrial fishery in 1981-83. Ibis, 132(2), 205217. doi: 10.1111/j.1474-919X.1990.tb01039.x

Furness, R., \& Tasker, M. (2000). Seabird-fishery interactions: quantifying the sensitivity of seabirds to reductions in sandeel abundance, and identification of key areas for sensitive seabirds in the North Sea. Marine Ecology Progress Series, 202, 253-264. doi: 10.3354/meps202253

Gimenez, O., Anker-Nilssen, T., \& Grosbois, V. (2012). Exploring causal pathways in demographic parameter variation: path analysis of mark-recapture data. Methods in Ecology and Evolution, 3(2), 427-432. doi: 10.1111/j.2041-210X.2011.00150.x

Goya, E. (2000). Abunduncia de aves guaneras y su relacion con la pesqueria de anchoveta peruana de 1953 a 1999.

Hedgren, S. (1975). The breeding population of Guillemot Uria aalge in the Baltic Sea. Vår Fågelvärld, 34, 43-52.

Hedgren, S. (1976). On the food of the common guillemot Uria aalge at the island of Stora Karlsö, the Baltic Sea.

Hilton, G. M., Furness, R. W., \& Houston, D. C. (2000). A comparative study of digestion in North Atlantic seabirds. Journal of Avian Biology, 31(1), 36-46. doi: 10.1034/j.1600048X.2000.310106.X

ICES. (2012). Report of the Working Group on Widely Distributed Stocks (WGWIDE). Lowestoft.

ICES. (2018). ICES Advice on fishing opportunities, catch, and effort. Sprat (Sprattus sprattus) in subdivisions 22-32 (Baltic Sea).

Jahncke, J., Checkley, D. M., \& Hunt, G. L. (2004). Trends in carbon flux to seabirds in the Peruvian upwelling system: effects of wind and fisheries on population regulation. Fisheries Oceanography, 13(3), 208-223. doi: 10.1111/j.1365-2419.2004.00283.x

Jarvis, M. J. F. (1974). The Ecological Significance of Clutch Size in the South African Gannet (Sula capensis (Lichtenstein). The Journal of Animal Ecology, 43(1), 1. doi: 10.2307/3154

Kadin, M., Olsson, O., Hentati-Sundberg, J., Ehrning, E. W., \& Blenckner, T. (2016). Common Guillemot Uria aalge parents adjust provisioning rates to compensate for low food quality. Ibis, 158(1), 167-178. doi: 10.1111/ibi.12335

Kadin, M., Österblom, H., Hentati-Sundberg, J., \& Olsson, O. (2012). Contrasting effects of food quality and quantity on a marine top predator. Marine Ecology Progress Series, 444, 239-249. doi: 10.3354/meps09417

Klages, N. T. W. (1994). Dispersal and site fidelity of Cap Gannets Morus Capensis. Ostrich, 65(2), 218-224. doi: 10.1080/00306525.1994.9639685

Laugksch, R. C., \& Duffy, D. C. (1984). Energetics equations and food consumption of seabirds in two marine upwelling areas: comparisons and the need for standardization. South African Journal of Marine Science, 2(1), 145-148. doi: $10.2989 / 02577618409504365$

Lockerbie, E. M., \& Shannon, L. (2019). Toward Exploring Possible Future States of the 
Southern Benguela. Frontiers in Marine Science, 6. doi: 10.3389/fmars.2019.00380 Lyngs, P., \& Durinck, J. (1998). Diet of Guillemots in the central Baltic Sea Diet of Guillemots Uria aalge in the central Baltic Sea. Retrieved from https://www.researchgate.net/publication/296665974

Martin, A. R. (1989). The diet of Atlantic Puffin Fratercula arctica and Northern Gannet Sula bassana chicks at a Shetland colony during a period of changing prey availability. Bird Study, 36(3), 170-180. doi: 10.1080/00063658909477022

Mitchell, P. I., Newton, S. F., Ratcliffe, N., \& Dunn, T. E. (2004). Seabird Populations of Britain and Ireland: results of the seabird 2000 census (1998-2002). Retrieved from http://www.jncc.defra.gov.uk/page1530.TofindoutmoreaboutJNCCvisithttp://www.jncc.defra.gov.uk/page-1729.

Nelson, J. B. (2005). Pelicans, Cormorants and their relatives Pelecanidae, Sulidae, Phalacrocoracidae, Anhingidae, Fregatidae, Phaethontidae. Oxford: Oxford University Press.

Oliveros-Ramos, R., \& Peña, C. (2011). Modeling and analysis of the recruitment of peruvian anchovy (Engraulis ringens) between 1961 and 2009. Ciencias Marinas, 37(4B), 659674. Retrieved from http://www.redalyc.org/articulo.oa?id=48021256010

Olsson, O., \& Hentati-Sundberg, J. (2017). Population trends and status of four seabird species (Uria aalge, Alca torda, Larus fuscus, Larus argentatus) at Stora Karlsö in the Baltic Sea. Ornis Svecica, 27(2-4), 64-93. doi: 10.34080/os.v27.19558

Österblom, H., \& Olsson, O. (2002). Changes in feeding behaviour and reproductive success in the Common Guillemot Uria aalge on the island of Stora Karlsö. Ornis Svecica, 12, 5362.

$\varnothing y a n$, H. S., \& Anker-Nilssen, T. (1996). Allocation of Growth in Food-Stressed Atlantic Puffin Chicks. The Auk, 113(4), 830-841. doi: 10.2307/4088861

Passuni, G., Barbraud, C., Chaigneau, A., Bertrand, A., Oliveros-Ramos, R., Ledesma, J., ... Bertrand, S. (2018). Long-term changes in the breeding seasonality of Peruvian seabirds and regime shifts in the Northern Humboldt Current System. Marine Ecology Progress Series, 597, 231-242. doi: 10.3354/meps12590

Passuni, G., Barbraud, C., Chaigneau, A., Demarcq, H., Ledesma, J., Bertrand, A., ... Bertrand, S. (2015). Seasonality in marine ecosystems: Peruvian seabirds, anchovy and oceanographic conditions. Ecology, 97(1), 150708023447006. doi: 10.1890/14-1134.1

Pedersen, J., \& Hislop, J. R. G. (2001). Seasonal variations in the energy density of fishes in the North Sea. Journal of Fish Biology, 59(2), 380-389. doi: 10.1111/j.10958649.2001.tb00137.x

Pichegru, L., Ryan, P., van der Lingen, C., Coetzee, J., Ropert-Coudert, Y., \& Grémillet, D. (2007). Foraging behaviour and energetics of Cape gannets Morus capensis feeding on live prey and fishery discards in the Benguela upwelling system. Marine Ecology Progress Series, 350, 127-136. doi: 10.3354/meps07128

Roth, J. E., Nur, N., Warzybok, P., \& Sydeman, W. J. (2008). Annual prey consumption of a dominant seabird, the common murre, in the California Current system. ICES Journal of Marine Science, 65(6), 1046-1056. doi: 10.1093/icesjms/fsn077

Sandvik, H., Erikstad, K. E., Fauchald, P., \& Tveraa, T. (2008). High survival of immatures in a long-lived seabird: insights from a long-term study of the Atlantic Puffin (Fratercula arctica). The Auk, 125(3), 723-730. doi: 10.1525/auk.2008.07059

Shannon, L. J., Ortego Cisneros, K., Lamont, T., H., W., Crawford, R. J. M., Jarre, A., \& Coll, M. (2020). Exploring temporal variability in the Southern Benguela ecosystem over the past 
four decades using a time-dynamic ecosystem model. Frontiers in Marine Science. doi: 10.3389/fmars.2020.00540

Toresen, R., \& Østvedt, O. J. (2000). Variation in abundance of Norwegian spring-spawning herring (Clupea harengus, Clupeidae) throughout the 20th century and the influence of climatic fluctuations. Fish and Fisheries, 1(3), 231-256. doi: 10.1111/j.14672979.2000.00022.x

Walsh, P., Halley, D., Harris, M., del Nevo, A., Sim, L., \& Tasker, M. (1995). Seabird monitoring handbook. Retrieved from http://nora.nerc.ac.uk/id/eprint/8798/1/Bird1.pdf 
ESM2: Supplementary tables

Table S1. Annual consumption of anchovy and sardine (combined) and proportion of diet comprised of anchovy and sardine, for key predators in the Southern Benguela. Estimates are those from a base-case model developed for 1978, from which dynamic simulations and model fitting has been performed (Lockerbie \& Shannon, 2019; Shannon et al., 2020).

\begin{tabular}{|c|c|c|c|}
\hline & & $\begin{array}{l}\text { Consumption of } \\
\text { anchovy and sardine } \\
\text { (tonnes/year) }\end{array}$ & $\begin{array}{l}\text { Combined \% } \\
\text { anchovy and } \\
\text { sardine in the diet of } \\
\text { the predators }\end{array}$ \\
\hline \multirow{3}{*}{ Seabirds } & Cape cormorant & 77000 & $98 \%$ \\
\hline & African penguins & 31000 & $79 \%$ \\
\hline & Cape gannet & 30000 & $58 \%$ \\
\hline \multirow{4}{*}{ Fish } & Snoek & Close to 100000 & $46 \%$ \\
\hline & Hake & 756000 & $\begin{array}{l}10-40 \% \text { depending } \\
\text { on size class }\end{array}$ \\
\hline & Yellowtail & 10000 & $30 \%$ \\
\hline & Geelbek & 4000 & $20 \%$ \\
\hline Cetaceans & $\begin{array}{l}\text { Cetaceans } \\
\text { Bryde's Whales }\end{array}$ & $\begin{array}{l}67000 \\
7000\end{array}$ & $\begin{array}{l}37 \% \\
\text { Based on Gwen } \\
\text { Penry's (pers. } \\
\text { comm.) calculations } \\
\text { and Best et al.'s } \\
\text { (1984) diet estimate } \\
\text { of around } 82 \% \\
\text { comprised of small } \\
\text { pelagics }\end{array}$ \\
\hline $\begin{array}{l}\text { Marine } \\
\text { mammals }\end{array}$ & Seals & 145000 & $30 \%$ \\
\hline Squids & Chokka squid & 31000 & $3 \%$ \\
\hline
\end{tabular}

